\title{
LYON NATURAL RADIOCARBON MEASUREMENTS VIII
}

\author{
J EVIN, G MARIEN, and C PACHIAUDI
}

Laboratoire de radiocarbone, Centre de Datation et d'Analyses isotopiques, Université Claude-Bernard de LYON

43 boulevard du 11 Novembre 1918, 69621 Villeurbanne FRANCE

\section{INTRODUCTION}

This list includes most of the measurements made in 1977 and 1978 using the two Packard liquid scintillation spectrometers described in Iyon VII (R, 1978, v 20, p 19). The backgrounds of both spectrometers decreased by about $30 \%$ with new photomultipliers, giving $1.9 \pm 0.1 \mathrm{cpm}$ and $2.4 \pm 0.2 \mathrm{cpm}$, respectively, for $3 \mathrm{ml} \mathrm{C}_{6} \mathrm{H}_{6}$ (depending on counting vessels). Proportional detectors are only used for very small samples. Counting procedures are described in the text. Dilution ratios indicate the amount of sample versus the total quantity of $\mathrm{C}_{6} \mathrm{H}_{6}$ or $\mathrm{CO}_{2}$ introduced in the detectors. No change was made either in chemical treatment or in the calculation method (half-life: $5570 \pm 0$, one standard deviation, standard ${ }^{13} \mathrm{C}$ correction only for bones).

\section{ACKNOWLEDGMENTS}

We thank Joëlle Maréchal and Gérard Drevon for their sample preparation and routine operation. We are indebted to L. David and $\mathrm{P}$ Elouard of the Dept of Geology for administrative and financial support, and we are grateful to the staff of the Nuclear Physics Institute for help and technical assistance.

\section{SAMPLE DESCRIPTIONS}

I. GEOLOGIC SAMPLES

\section{A. Samples from peat bogs of low altitudes}

\section{Ly-1669. Marais de Lavours, Vongnes, Ain Modern}

Plant debris from alluvial sediments of Le Séran $\mathrm{R}$ at Les Rosières in Le Marais peat bog, near Vongnes, Ain $\left(45^{\circ} 49^{\prime} \mathrm{N}, 5^{\circ} 39^{\prime} \mathrm{E}\right)$. Coll and subm 1975 by R Vilain, Geol Dept, Univ Lyon. Comment (RV): indicates that sample deposited by recent fluctuation of Le Séran R, and is unrelated to filling of Lavours peat bog.

\section{Ly-1044. Marais de Saint-Gond, Morains, Marne $1530 \pm 120$}

Sediment rich in organic matter from boring in sediments of upper course of Petit Morin R, near Morains, Marne (48 $\left.48^{\prime} \mathrm{N}, 3^{\circ} 59^{\prime} \mathrm{E}\right)$. Coll and subm by $\mathrm{F}$ Megnien, Bur recherches Geol Min, Brie-Comte-Robert. Peat thickness established in E termination of Saint-Gond peat bog which was formed by capture of upper course of Petit Morin $\mathrm{R}$ by Somme Soude R. Comment (FM): approximately indicates when occurred, but further studies are necessary 


\section{Aigues-Mortes series, Gard}

Sediments, mainly organic debris, deposited by branches of Rhône $\mathrm{R}$ in $\mathrm{W}$ part of its delta, near Aigues-Mortes, Gard. Coll by A L'Homer and subm by A Marcé, Bur recherches Geol Min, Orléans La Source.

\section{Ly-1041. Rempart LU2, Aigues-Mortes}

$1980 \pm 130$

Pure powdered plant remains coll at $0.4 \mathrm{~m}$ depth between 2 ancient offshore bars (see Le Grau du Roi series, below) just outside Medieval walls of Aigues-Mortes city (43 $\left.35^{\prime} \mathrm{N}, 4^{\circ} 12^{\prime} \mathrm{E}\right)$. Coll and subm 1975.

\section{Ly-1264. Le Canet, Aigues-Mortes}

$1720 \pm 130$

Sandy powdered plant remains coll at $0.6 \mathrm{~m}$ depth on side of ancient lagoon, in connection with Lairon pond. Vegetals were deposited by an ancient lateral channel of Paccaïs Rhône $\mathrm{R}$ at Mas du Canet $\left(43^{\circ} 33^{\prime} \mathrm{N}\right.$, $\left.4^{\circ} 14^{\prime} \mathrm{E}\right)$. Coll and subm 1976.

General Comment (AL): both dates agree and are max for closing of fluvial drift system near Aigues-Mortes.

\section{Ly-1040. Marais de Fourchon, Arles, Bouches du Rhône}

$\mathbf{5 8 5 0} \pm \mathbf{2 4 0}$

Peaty sediment rich in organic matter from $8.5 \mathrm{~m}$ depth at base of SA 1 or SA 3 boring in Fourchon peat bog near Arles, Bouches du Rhône $\left(43^{\circ} 40^{\prime} \mathrm{N}, 4^{\circ} 38^{\prime} \mathrm{E}\right)$. Coll 1975 by A L'Homer and subm 1975 by A Marcé. Pollen diagram studied by $\mathrm{H}$ Triat, Lab Bot Hist, Univ AixMarseille, 2/3 diluted sample. Comment (AL and HT): formation of Fourchon peat bog occurred behind offshore bar formed during period of stable sea level. At this level, pollen diagram indicates development of Fagus forest, which, according to botanic data in region (Triat-Laval, 1978), has been attributed to the Atlantic period. Date agrees with Ly1038, below, and with unpub result from $9.1 \mathrm{~m}$ depth at same site: MC$1165,6580 \pm 100$ вр.

\section{Marais de Meyranne series, Raphèle lès Arles, Bouches du Rhône}

Peat from 3 levels of SA 4 boring in Meyranne peat bog, near

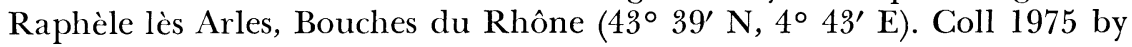
A L'Homer and subm 1975 by A Marcé. Pollen diagram studied by $\mathrm{H}$ Triat.

Ly-1037. Marais de Meyranne, 2

$2930 \pm 270$

From $2 \mathrm{~m}$ depth, $1 / 6$ diluted sample.

Ly-1038. Marais de Meyranne, 4.3

$5010 \pm 310$

From $4.3 \mathrm{~m}$ depth, $1 / 2$ diluted sample.

Ly-1039. Marais de Meyranne, 6

From $6.0 \mathrm{~m}$ depth, $1 / 6$ diluted sample.

$8010 \pm 400$

General Comment (AL \& HT): like Fourchon and Fos peat bogs, Meyranne peat bog grew behind offshore bar during same period of stable 
sea level. Pollen diagram shows beginning of climatic improvement phase at level of Ly-1039, above stratigraphic lacuna. Ly-1038 is just before increase of Fagus curve that remains constant until deforestation by humans, a little after Ly-1037 at level of which Abies disappears, (TriatLaval, 1978).

\section{Les Courtins series, Muron, Charente Maritime}

Peat from 2 levels of 658/3/501 boring in Scrobicularia clays "Bri", of Rochefort peat bog at Les Courtins, near Muron, Charente Maritime $\left(46^{\circ} 2^{\prime} \mathrm{N}, 0^{\circ} 49^{\prime} \mathrm{W}\right)$. Coll 1975 by B Bourgueil, Bur recherche Geol Min, Poitiers, and subm 1975 by A Marcé.

Ly-1042. Les Courtins, 14m

$8380 \pm 250$

From $14.03 \mathrm{~m}$ to $14.05 \mathrm{~m}$ depth, $2 / 3$ diluted sample.

Ly-1043. Les Courtins, 16m

$8140 \pm 330$

From $16.07 \mathrm{~m}$ to $16.10 \mathrm{~m}$ depth, $1 / 3$ diluted sample.

General Comment (BB): considering counting error, both dates are similar, indicating rapid sedimentation and confirming expected Holocene age.

\section{Canal de la Fure series, Charavines, Isère}

Peat from top and base of peaty layer, $1 \mathrm{~m}$ thick, submerged at $1.3 \mathrm{~m}$ in Fure channel, artificial overflow of Paladru lake at Charavines, Isère $\left(45^{\circ} 25^{\prime} \mathrm{N}, 5^{\circ} 31^{\prime} \mathrm{E}\right)$. Coll and subm 1978 by M Girard and A Bocquet, Inst Dolomieu, Grenoble.

\section{Ly-1663. Canal de la Fure, Sommet}

From top of peat layer, underlying lacustrian chalk layer.

\section{Ly-1664. Canal de la Fure, Base}

$4780 \pm 150$

From base of peat layer, overlying another lacustrian chalk layer.

General Comment (AB): Late Neolithic settlement on lowest lacustrine chalk layer in neighboring Les Baigneurs bay gave numerous pub dates from 4440 to 4100 BP (R, 1976, v 18, p 73). Between both dates lake level probably rose slowly to allow growth of homogeneous peat layer without clay and chalk. Waters rose high enough to involve chalk layer overlying present submerged Medieval (12th century) settlement.

\section{Le Moulin de Siarne series, Ebréon, Charente}

Peat from $240 \mathrm{~m}$ neighbouring excavations in Aigre peat bog at Le Moulin de Siarne near Ebréon, Charente $\left(45^{\circ} 57^{\prime} \mathrm{N}, 0^{\circ} 01^{\prime} \mathrm{E}\right)$. Coll and subm 1976 by Y Guillien, Bourg la Reine. Peat interstratified in calcareous tufa rich in organic matter and called "Bouchot".

Ly-1620. Moulin de Siarne II

$4800 \pm 150$

From $2 \mathrm{~m}$ depth in excavation near side of peat bog. 
Ly-1619. Moulin de Siarne I

From $6 \mathrm{~m}$ depth in excavation near middle of peat bog.

General Comment (YG): as peaty layer in Excavation II dips towards Excavation $I$ and both dates are in $2 \sigma$ statistical margins, peat may be only one layer which occurred during Atlantic period. This indicates quick growth for $6 \mathrm{~m}$ thickness of "Bouchot".

\section{Le Parc Borély series, Marseille, Bouches du Rhône}

Peat from 2 levels of boring in town park Borély in Le Prado

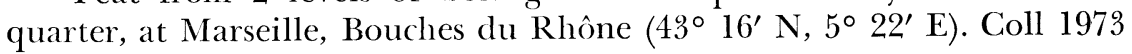
and subm 1977 by $\mathrm{H}$ Triat.

Ly-1466. Parc Borély, 395cm

Ly-1467. Pare Borély, 590cm

$6380 \pm 140$

General Comment (HT): both dates agree with expected ages. Pollen diagram indicates disappearance of Tilia, Ulmus, and Quercus pubescens. This demonstrates rapidity and amount of deforestation in Marseille region where 1st clearing of woods by humans occurred during Neolithic period at Ly-1467 level (Triat-Laval, 1978).

\section{Marais des Grands Paluds series, Fos sur Mer, Bouches du Rhône}

Peaty sediments from 3 close borings in $\mathrm{N}$ part of Les Grands Paluds peat bog, near Fos sur Mer, Bouches du Rhône (43 $\left.28^{\prime} \mathrm{N}, 4^{\circ} 52^{\prime} \mathrm{E}\right)$. Coll and subm 1977 by H Triat-Laval.

\section{Ly-1493. Les Grands Paluds de Fos, 130 to} $135 \mathrm{~cm}$, No. 1

Peat coll from 130 to $135 \mathrm{~cm}$ depth by plastic tubing drill; pollen diagram indicates late increase of Fagus in Sub-Atlantic period.

\section{Ly-1494. Les Grands Paluds de Fos, 130 to $135 \mathrm{~cm}$, No. 2}

Peat from same level as Ly-1493 but coll by Smith's drill.

Ly-1495. Les Grands Paluds de Fos, $140 \mathrm{~cm} \quad 3000 \pm 130$ depth.

Clay, rich in organic matter, coll by plastic tubing drill at $140 \mathrm{~cm}$

Ly-1496. Les Grands Paluds de Fos, 184

to $189 \mathrm{~cm}$

$4450 \pm 300$

Peat, little evolved from 184 to $189 \mathrm{~cm}$ depth, coll by sovietic drill. $1 / 5$ diluted sample. Pollen diagram indicates beginning of continuous curve of Fagus in Sub-Boreal period.

General Comment (HT): Ly-1493 and -1494, from same level, coll to test 2 boring systems in very wet peat bog where peaty sediment remains fluid. As expected, similarity of both results excludes mixture contamination of samples. Pollen diagram indicates beginning of Sub-Boreal period at level of Ly-1496, which then agrees with generally proposed chronol- 
ogy for beginning of this climatic phase. Hiatus occurred in sedimentation between Ly-1493/1494 and Ly-1495 at about limit of Sub-Boreal and Sub-Atlantic periods. Previously pub value, Ly-364: $5600 \pm 150$ (R, 1973, $\mathrm{v} 15, \mathrm{p} 136$ ) from $4.1 \mathrm{~m}$ depth in $S$ part of peat bog, at Le Pont des Clapets, fits with present series and corresponds to end of Atlantic (TriatLaval, 1978).

\section{Les Paluds series, Courthézon, Vaucluse}

Peat from 2 levels of boring with Smith's drill in Les Paluds peat bog, near Courthézon, Vaucluse $\left(44^{\circ} 5^{\prime} \mathrm{N}, 4^{\circ} 53^{\prime} \mathrm{E}\right)$. Coll 1975 and subm 1977 by $\mathrm{H}$ Triat to complete and confirm 5 previously pub dates (R, 1978, v 20, p 20).

\section{Ly-1465. Les Paluds de Courthézon, 260} to $265 \mathrm{~cm}$

$4250 \pm 250$

Peat from 260 to $265 \mathrm{~cm}$ depth where pollen diagram indicates beginning of Fagus extension, 1/2 diluted sample. Comment (HT): date a little younger than generally accepted (4700 вP) age of this pollen event in $\mathrm{N}$ Europe.

\section{Ly-1582. Les Paluds de Courthézon, 480 to $500 \mathrm{~cm}$}

Peat from 480 to $500 \mathrm{~cm}$ depth, underlying level dated by Ly-1136: $11,530 \pm 230,470$ to $475 \mathrm{~cm}$ deep. Comment (HT): confirms previous result; indicates either complex evolution of vegetation during Alleröd period or rejuvenation of all samples from base of boring, due to local edaphic conditions.

General Comment (HT): 2 present results and previous series show vegetation history since Tardiglacial period. Extension of Pinus forest from Alleröd (Ly-1582/1136) or earlier (contamination) to Pre-Boreal (Ly-1263) is interrupted by phase of more steppe-like vegetation during Late Dryas. Short extension of Corylus may be seen at Boreal period (Ly-1262). First appearances of Abies, after those of Quercus ilex occurred in Atlantic period (Ly-1135) and increase of Fagus mark beginning Sub-Boreal (Ly1465). Human influence may be detected as soon as Neolithic time.

\section{Les Autures series, L'Isle sur la Sorgue, Vaucluse}

Peat from 3 levels of boring in ancient Les Autures peat bog, near

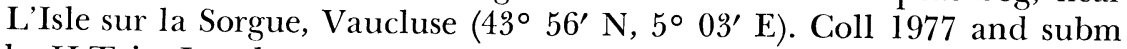
by $\mathrm{H}$ Triat-Laval.

\section{Ly-1563. Les Autures, 129 to $132 \mathrm{~cm}$}

From 129 to $132 \mathrm{~cm}$ depth, $1 / 3$ diluted sample. Pollen diagram indicates beginning of Fagus curve. Comment (HT): seems to be a little too old with respect to Ly-1465, above, for same botanic event but agrees with previously pub date, Ly-911: $4450 \pm 150(\mathrm{R}, 1976, \mathrm{v} 18, \mathrm{p} 62)$ at nearby site. 
Ly-1564. Les Autures, 149 to $151 \mathrm{~cm} \quad 6020 \pm 230$

From 149 to $151 \mathrm{~cm}$ depth, 9/10 diluted sample. Comment (HT): just before level, pollen diagram has continuous curve of Abies consistent with prosperity of fir forests in South Alps as, for instance, shown by Col des Lauzes and Lac Long Inférieur series (R, 1978, v 20, p 27-29; de Beaulieu, 1977). After level, Abies curve reflects regional fir forest.

Ly-1565. Les Autures, 303 to $307 \mathrm{~cm}$

$7610 \pm 190$

From 303 to $307 \mathrm{~cm}$ depth, assumed from Atlantic period. Comment (HT): agrees with Ly-910: $6880 \pm 180(\mathrm{R}, 1976, \mathrm{v} 18, \mathrm{p}$ 62) from L'Isle sur la Sorgue, neighboring site, and may mark beginning of Atlantic period, with small frequency of Quercus pubescens but without Quercus ilex and Abies pollen

\section{Barbegal series, Arles, Bouches du Rhône}

Samples from several levels of boring made by sovietic drill in Bar-

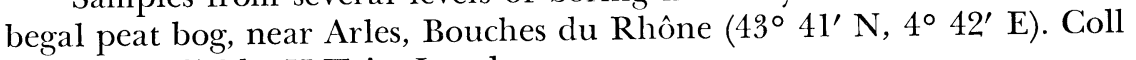
and subm 1976 by H Triat-Laval.

\section{Ly-1460. Barbegal 80-85}

$3670 \pm 140$

Peat from 80 to $85 \mathrm{~cm}$ depth. Pollen diagram indicates decrease of Betula and Quercus pubescens and increase of Fagus and Quercus ilex.

\section{Ly-1461. Barbegal 120}

$5140 \pm 130$

Peat from $120 \mathrm{~cm}$ depth. Pollen diagram indicates beginning of continuous curve of Abies which should correspond to Atlantic A period.

\section{Ly-1462. Barbegal 160}

$5160 \pm 230$

Peat from $160 \mathrm{~cm}$ depth, $2 / 3$ diluted sample. Pollen diagram indicates beginning of Fagus curve which could correspond to beginning of Atlantic A period.

\section{Ly-1463. Barbegal 240}

$6860 \pm 340$

Peaty clay from $240 \mathrm{~cm}$ depth, at base of boring, $1 / 3$ diluted sample. At overlying depth, $235 \mathrm{~cm}$, Quercus ilex pollens could imply pre-Atlantic date for lowest levels of site (Triat-Laval, 1978).

General Comment (HT): Ly-1460 proves early human influence by clearing of woods which favored Fagus extension. Time proximity of Ly-1461 and -1462 , despite $40 \mathrm{~cm}$ distance, shows very rapid filling. Ly-1463 seems too young for hypothesis of pre-Atlantic sediment at base of Barbegal peat bog.

\section{Marais des Baux series, Mouriès, Bouches du Rhône}

Organic sediments from several levels of borings coll by Smith`s drill in middle of Les Beaux dried peat bog, near Mouriès, Bouches du Rhône $\left(43^{\circ} 41^{\prime} \mathrm{N}, 4^{\circ} 48^{\prime} \mathrm{E}\right)$. Coll 1976 and subm 1977 by H Triat-Laval. 
Ly-1504. Les Baux 70-75

$3370 \pm 190$

Dark gray marl from 70 to $75 \mathrm{~cm}$ depth. Just below curve of Quercus ilex and Fagus begins, while Pinus falls sharply. Comment (HT): same pollen event and date in Barbegal site: Ly-1460, above.

Ly-1505. Les Baux 85-90

$3100 \pm 290$

Clear gray marl from 85 to $90 \mathrm{~cm}$ depth, $2 / 3$ diluted sample. Pollen diagram shows beginning of Fagus curve. Comment (HT): younger than expected for Fagus appearance with respect to Ly-1040 at Le Fourchon and Ly-1563 at Les Autures peat bogs, above.

Ly-1506. Les Baux 120-125

$\mathbf{5 1 8 0} \pm 390$

Very clear gray marl with small organic content, $1 / 5$ diluted sample, from 120 to $125 \mathrm{~cm}$ depth. Beginning of Abies curve in pollen diagram. Comment (HT): shows more recent age for Abies appearance than in Courthézon site: Ly-1135, $7350 \pm 170(\mathrm{R}, 1978, \mathrm{v} 20$, p 20).

Ly-1507. Les Baux 155-160

$7260 \pm 1140$

Chalky marl with very poor organic content, $1 / 15$ very diluted sample, from 155 to $160 \mathrm{~cm}$ depth. Comment (HT): too young, as pollen diagram defines end of pre-Boreal period.

Ly-1464. Les Baux 245-255

$8130 \pm 750$

White clay with some organic debris, $1 / 10$ very diluted sample, from 245 to $255 \mathrm{~cm}$ depth. Comment (HT): too young, as pollen diagram indicates pre-Boreal period.

Ly-1508. Les Baux 280-285

$9750 \pm 960$

Sandy gray clay with very low organic content, $1 / 15$ very diluted sample. Pollen diagram shows an increase of Pinus probably during preBoreal period. Comment (HT): contrary to 2 previous results, and considering large counting error, date agrees with Ly-1558 from BeauchampPanières site, below.

General Comment (HT): all results from this site seem too young except those from samples with normal organic content. Discrepancies may be due to clayey nature of sediments or to another unknown reason, specific to sampling site (Triat-Laval, 1978).

\section{Beauchamp-Panières series, Saint-Rémy de Provence, Bouches du Rhône}

Samples from several levels in borings coll by Smith's drill in Beauchamp-Panières ancient peat bog, near Saint-Rémy de Provence, Bouches du Rhône ( $43^{\circ} 32^{\prime}$ N, $4^{\circ} 53^{\prime}$ E). Coll and subm 1977 by H Triat.

\section{Ly-1554. Beauchamp-Panières, 85-90}

$8320 \pm 510$

Gray marl with low organic content, $1 / 3$ diluted sample. From 85 to $90 \mathrm{~cm}$ depth. Pollen data corresponding to beginning of Atlantic period. Comment (HT): date is younger than expected and disagrees with results below as well as with pollen data. 


\section{Ly-1555. Beauchamp-Panières, 95-100 $6770 \pm 450$}

Gray marl with low organic content, $1 / 5$ diluted sample, from 95 to $100 \mathrm{~cm}$ depth. Just before Abies appearance that corresponds to Atlantic A period. Comment (HT): younger than expected by Ly-1135: 7350 上 170 for pollen event in Courthézon site ( $R, 1978$, v 20, p 20), but agrees with Ly-910: $6880 \pm 180(\mathrm{R}, 1976, \mathrm{v} 18, \mathrm{p}$ 62) from L'Isle sur la Sorgue site.

\section{Ly-1556. Beauchamp-Panières, 120-125 $\quad 8210 \pm 700$}

Gray marl with few plant remains, $1 / 10$ very diluted sample, from 120 to $125 \mathrm{~cm}$ depth. Pollen diagram indicates extension of Quercus pubescens forest. Comment (HT): agrees with expected age and Ly-1262: $8480 \pm 200$ from Les Paluds de Courthézon and Ly-1019: $7880 \pm 200$ for Mollègès sites (R, 1978, v 20, p 20).

Ly-1557. Beauchamp-Panières, 136-140 $\quad 8390 \pm 210$

Peat from 136 to $140 \mathrm{~cm}$ depth. A high but short extension of Corylus occurs at level attributed to Boreal period. Comment (HT): confirms attribution and also agrees with Ly-1262 (see above).

Ly-1558. Beauchamp-Panières, 143-146 $10,140 \pm 220$

Peaty marl from 143 to $146 \mathrm{~cm}$ depth, just before a sedimentation hiatus. Comment (HT): may attribute max Pinus forest in beginning of Pre-Boreal period.

Ly-1559. Beauchamp-Panières, 220-225 $11,320 \pm 1060$

Sandy clay, very poor in organic matter, $1 / 10$ very diluted sample, from 220 to $225 \mathrm{~cm}$ depth. Pollen diagram implies end of Alleröd period. Comment (HT): despite very large counting error, date agrees with expected period.

Ly-1560. Beauchamp-Panières, 328-332 $12,740 \pm 480$

Gray marl from 328 to $332 \mathrm{~cm}$ depth, $1 / 2$ diluted sample. Pollen diagram shows phase of better climate with presence of Quercus pubescens and Corylus, which may correspond to Alleröd and Bölling periods as middle Dryas period cannot be seen in any pollen diagram in region.

Ly-1561. Beauchamp-Panières, 395-400 $12,580 \pm 640$

Sandy gray clay with some plant debris from 395 to $400 \mathrm{~cm}$ depth, $1 / 3$ diluted sample. Pollen data should suggest Early Dryas. Comment (HT): date agrees with assumed climatic period only with $2 \sigma$ statistical margin.

\section{Ly-1562. Beauchamp-Panières, 40-50 $\quad 12,320 \pm 1020$}

Gray clay with small organic matter content from base of another boring coll by sovietic drill, $1 / 5$ diluted sample. Pollen diagram comparison here makes oldest date of site expected. Comment (HT): much too close to Ly-1560 and -1561, date is younger than expected. Thus, most samples from bases of borings yield less reliable results which may be due to small amount of available organic matter. 
General Comment (HT): pollen history of site begins with no mesothermic sp but with a steppe phase which may be contaminated by younger carbon. Subsequent increase of Quercus pubescens, Alnus, and Corylus pollen initiated a long phase (Ly-1559 and -1560) of Pinus forest of which max occurred during Boreal period. Late Dryas (Ly-1558) is very well marked by decrease of arboreal pollen. Extension of Quercus forest 1st due to $Q$. pubescens (Ly-1556) sp then to Q. ilex at Atlantic period where human influence becomes apparent. Abies appears at Atlantic period (Ly-1555) followed by Fagus at beginning of Sub-Boreal (Triat-Laval, 1978).

\section{B. Samples from peat bogs of high altitudes}

\section{Dar Fatma series, Aïn Draham, Tunisia}

Peat from 2 levels of core coll by Coûteaux' drill in Dar Fatma peat bog at $910 \mathrm{~m}$ alt, near Aïn Draham, Tunisia (36 $\left.46^{\prime} \mathrm{N}, 8^{\circ} 42^{\prime} \mathrm{E}\right)$. Coll 1977 by A Pons and subm 1978 by A Pons and M Reille, Lab Bot Hist and Palynol, Univ Marseille.

\section{Ly-1627. Dar Fatma, Sommet}

$$
\begin{array}{r}
\text { Modern } \\
\delta^{14} \mathrm{C}=+\mathbf{2 0 . 0 \%} \pm \mathbf{3 . 0} \\
\mathbf{7 0 9} \pm \mathbf{1 1 0}
\end{array}
$$

Ly-1650. Dar Fatma, 63 to $71 \mathrm{~cm}$

General Comment (MR): pollen diagram shows last great deforestation just before Ly-1650. As shown in pollen diagram from Moroccan Rif (Reille, 1977) this event is a consequence of Arabian invasion.

\section{Ly-1335. Col de Zad, Azrou, Morocco $1150 \pm 120$}

Peat from 70 to $72.5 \mathrm{~cm}$ depth of core coll by Coûteaux' drill at alt $2000 \mathrm{~m}$ at Le Col de Zad, near Azrou, Morocco $\left(33^{\circ} 00^{\prime} \mathrm{N}, 5^{\circ} 03^{\prime} \mathrm{W}\right)$. Coll 1971 and subm by M Reille. Pollen diagram indicates disappearance of deciduous Quercus (Reille, 1976). Comment (MR): base of core gave unpub date: Lv-672, $2860 \pm 60$ and transition between Sub-Boreal and Sub-Atlantic periods cannot be seen in pollen diagram where deciduous Quercus should be reliable marker.

\section{Ly-1233. Tizirène, Bab Taza, Morocco}

$$
1390 \pm 140
$$

Peat with Cyperaceae sp from 130 to $140 \mathrm{~cm}$ of core coll by Coûteaux' drill at alt $1400 \mathrm{~m}$ in pond at Tizirène, near Bab Taza, Rif, Morocco $\left(35^{\circ} 01^{\prime} \mathrm{N}, 5^{\circ} 00^{\prime} \mathrm{W}\right)$. Coll 1971 and subm 1976 by M Reille. Should correspond to Sub-Atlantic phase, before olive cultivation which began in Rif region ca 1000 вр. Comment (MR): agrees with expected age and approximates date of base of core from a neighboring pond, top of which yielded unpub date: Lv-647, younger than 210 вр (Reille, 1977).

\section{Ly-1459. Oukaïmeden, Marrackech, Morocco $1610 \pm 140$}

Peat from 115 to $120 \mathrm{~cm}$ depth in core coll at alt $2600 \mathrm{~m}$ in Agdal of Oukaïmeden, near Marrackech, Morocco (31 $\left.{ }^{\circ} 12^{\prime} \mathrm{N}, 7^{\circ} 51^{\prime} \mathrm{W}\right)$. Coll 1971 and subm 1976 by M Reille. Pollen diagram indicates disappearance of Quercus at level. Comment (MT): consistent with unpub result from 
$150 \mathrm{~cm}$ depth in core, Lv-693: $2680 \pm 50 \mathrm{BP}$, which marks end of SubBoreal. As in Col de Zad site, above, transition from Sub-Boreal to SubAtlantic periods is not botanically characterized. Disappearance of deciduous Quercus is probably due to dry tendency during Sub-Atlantic period and may be used as marker for region.

\section{Pélléautier series, Haute Alpes}

Samples from levels of several cores close to each other in La-Mottequi-Tremble peat bog, near Pélléautier, Hautes Alpes $\left(44^{\circ} 31^{\prime} \mathrm{N}, 6^{\circ} 11^{\prime}\right.$ E). Cores I and III were coll by Coûteaux' drill in 1971 and Cores IV, V, and VI by Smith's drill in 1973, 1973 and 1976 respectively. Samples subm and pollen diagrams studied by J L de Beaulieu as part of general study of South Alps late and postglacial vegetation. All other Lyon radiocarbon results were pub previously (R, 1978, v 20, p 22-30). Site lies at alt $975 \mathrm{~m}$ on side of Céüze $\mathrm{mt}$ ca $400 \mathrm{~m}$ above large glacial valley of Durance R. Because of its very open position in landscape, site may well reflect vegetational history of region (de Beaulieu, 1977), and studies on coll cores are still in process. Often due to scarcity of organic matter in lowest levels, difficulties encountered in countings sometimes involved large counting errors and control measurements. Numbers indicate depths in cores and climatic phases are deduced from pollen diagrams.

\section{Ly-581. Pélléautier I, 70 to $75 \mathrm{~cm}$}

$660 \pm 210$

Gray clayey peat with mollusk shells. Disappearance of Abies and Quercus, appearance of Juglans and many non-arboreal pollens. High deforestation probably due to Middle age grazing fields, 5/6 diluted sample.

\section{Ly-797. Pélléautier I, $260 \mathrm{~cm}$}

$4640 \pm 190$

Black peat, $20 \mathrm{~cm}$ above limit of lacustrine chalk, Abies predominance, end of Atlantic period.

\section{Ly-582. Pélléautier III, 145 to $150 \mathrm{~cm}$}

$4850 \pm 250$

Lacustrine chalk with low organic content giving a $7 / 12$ diluted sample. Pollen diagram demonstrates large hiatus at $39 \mathrm{~cm}$ depth in boring made on peat bog side. Predominance of Pinus Pre-Boreal or Alleröd. Comment (JL de B): aberrant result may be due to sampling system or secondary disturbance in levels.

Ly-1211. Pélléautier IV, 175 to $180 \mathrm{~cm}$

$6430 \pm 190$

Peat, predominance of Abies. Atlantic period.

Ly-1212. Pélléautier IV, 185 to $195 \mathrm{~cm} \quad 7600 \pm 230$

Peat, Pinus predominance, Quercus presence and beginning of continuous curve of Abies; end of Boreal period.

Ly-1213. Pélléautier IV, 305 to $315 \mathrm{~cm}$

$9090 \pm 230$

Peat from lst peaty level above lacustrine chalk, Pinus predominance on mesothermic sp, Pre-Boreal. 
Ly-1214. Pélléautier IV, 465 to $475 \mathrm{~cm}$

$11,000 \pm 460$

White chalk with little organic content involved counting in proportional detectors even after $1 / 2$ dilution of sample. Only Pinus with some Betula pollen; Alleröd or Bölling phase.

Ly-1215. Pélléautier IV, 504 to $513 \mathrm{~cm}$

$11,750 \pm 500$

Same as Ly-1214 for dating material, pollen date and counting procedure but without dilution.

Ly-1216. Pélléautier IV, 540 to $550 \mathrm{~cm} \quad 13,210 \pm 410$

Gray marl with higher content of carbon precluding dilution before measurement in small counters. Short shift of Pinus pollen percentage due to somewhat larger quantity of Betula pollens. End of continuous curve of Juniperus. Max of Betula is presumed during Bölling period.

Ly-1218. Pélléautier V, 565 to $574 \mathrm{~cm}$

$14,320 \pm 680$

Marl with small organic content involving 3/4 diluted sample and measurement in proportional detectors. Predominance of Juniperus with Betula and Pinus presence; early Dryas.

Ly-1217. Pélléautier V, 587 to $595 \mathrm{~cm}$

$10,990 \pm 660$

Same dating material and counting procedure with $4 / 7$ dilution. Before Juniperus max. Large amount of Pinus pollen, Early Dryas. Comment (JL de B): aberrant result for unknown reason.

\section{Ly-1775. Pélléautier VI, 415 to $422 \mathrm{~cm}$}

$12,810 \pm 280$

Peaty clear marl with many shells. Beginning of Pinus forest extension corresponding to large Betula decrease and end of Juniperus continuous curve; beginning of Bölling-Alleröd period.

Ly-1776. Pélléautier VI, 462 to $470 \mathrm{~cm}$

$13,200 \pm 550$

Gray marl with plant debris and shells, $1 / 2$ diluted sample, min of Pinus, max of Juniperus, just before expansion of Betula; before or during beginning of Bölling-Alleröd period.

Ly-1342. Pélléautier VI, 545 to $555 \mathrm{~cm}$

$15,300 \pm 320$

Marl rich in organic debris but poor in pollen. Predominance of Juniperus. Comment (JL de B): does not fit with all other results for unknown reason.

Ly-1794. Pélléautier VI, 605 to $615 \mathrm{~cm}$

$14,560 \pm 420$

Peaty marl with organic debris and shells, beginning of first Juniperus max; before Bölling. Same pollen proportion in Core V at Ly-1218 level, $4 / 5$ diluted sample.

Ly-1795. Pélléautier VI, 620 to $625 \mathrm{~cm} \quad 15,090 \pm 430$ sample.

Peaty marl, just before beginning of 1st Juniperus max, $3 / 5$ diluted

Ly-1468. Pélléautier VI, 625 to $635 \mathrm{~cm}$

$14,770 \pm 300$

Same material and pollen event as Ly-1795. 


\section{Ly-1796. Pélléautier VI, 690 to $708 \mathrm{~cm}$}

Clay very poor in organic matter, 4/30 very diluted sample and long counting time. Pollen diagram shows some changes in composition of steppe-like vegetation together with reduced percentage of long distance pollen (Pinus) Down to the base of core, at $780 \mathrm{~cm}$ depth, sediment and pollen composition remain similar.

General Comment (JL de B): on 18 results, only Ly-582 and -1217 are not consistent for unknown reasons. All other dates give continuous chronology of site vegetation that fits very well with generally accepted absolute chronology of assumed climatic phases. Dates also agree with most values from neighboring sites, such as Siguret (de Beaulieu, 1977), Saint-Léger, Le Forest and Les Lauzes series (R, 1978, v 20, p 24-27) where last max of Juniperus, 1st max of Pinus, and appearance of Abies, are contemporaneous. Oldest dates are more interesting as they establish, for lst time, an absolute chronology within Early Dryas period during steppe-like and steppe-bush phases. Nevertheless, Ly-1796 needs confirmation with further measurements on largest samples.

\section{Bone samples from fill of grottos}

Ly-1292. Aven du Nonoss, Entremont le Vieux, Savoie $4210 \pm 160$

Bones (Bovidae) from base of Le Nonoss "aven", near Entremont le Vieux, Savoie $\left(45^{\circ} 27^{\prime} \mathrm{N}, 5^{\circ} 54^{\prime} \mathrm{E}\right)$. Coll 1975 by $M$ Ulysse and subm 1975 by M Philippe, Hist Nat Mus Lyon. Comment (MP): much younger than expected but may fit with fauna.

\section{Causse du Gramat series, Lot}

Bones from various fauna from fillings of several "avens", holes or grottos scattered on kastified calcareous plateau. Causse de Gramat, between valleys of Dordogne and Lot R, Lot dept. Samples were coll during survey of paleontol sites to complete previous pub series (R, 1975, v 17, p 13) by M Philippe.

\section{Ly-1578. Igues de Bramarie, Diaclase supérieure,} Caniac du Causse $\quad 1900 \pm 600$

Bones (Equidae) found close to entrance of Igues de Barrière aven, near Caniac du Causse, Lot $\left(44^{\circ} 39^{\prime} \mathrm{N}, 1^{\circ} 37^{\prime} \mathrm{E}\right), 1 / 10$ very diluted sample. Coll 1975 and subm 1976.

\section{Ly-1577. Igues de Bramarie, Conduite forcée,} Caniac du Causse $\quad 2880 \pm 630$

Bones (Bovidae) from $40 \mathrm{~m}$ depth at base of Igues de Bramarie aven, near Caniac du Causse, Lot $\left(44^{\circ} 39^{\prime} \mathrm{N}, 1^{\circ} 37^{\prime} \mathrm{E}\right), 1 / 6$ very diluted sample. Coll 1975 and subm 1976. 
Ly-1367. Igues du Pepin, Caniac du Causse

$5350 \pm 380$

Bones from various fauna from 25 to $35 \mathrm{~m}$ depth between aven-shafts 2 and 3 of Le Pépin aven, near Caniac du Causse, Lot $\left(44^{\circ} 38^{\prime} \mathrm{N}\right.$, $1^{\circ} 40^{\prime} \mathrm{E}$ ), $1 / 3$ diluted sample. Coll 1971 and subm 1976. Comment (MP): as some sp of fauna are obviously Würmian, such as reindeer, date proves mixture of ancient and recent bones in sites.

Ly-1576. Igues de Barrière, Miers

$19,940 \pm 800$

Bones (Bovidae) from $40 \mathrm{~m}$ depth at base of Igues de Barrière aven, near Miers, Lot $\left(44^{\circ} 53^{\prime} \mathrm{N}, 1^{\circ} 42^{\prime} \mathrm{E}\right), 2 / 3$ diluted sample. Coll 1972 and subm 1976.

\section{Ly-1294. Perte de Bramarie, Caniac du} Causse, Lot

Bones (Elephas) from 50m depth at base of Perte de Bramarie aven, near Caniac du Causse, Lot $\left(44^{\circ} 39^{\prime} \mathrm{N}, 1^{\circ} 37^{\prime} \mathrm{E}\right)$. Coll 1974 and subm 1975.

General Comment (MP): as shown by dilution ratios, organic contents of bones is variable and, here, inversely proportional to absolute age. Loss of organic carbon in bones depends mainly on burial since more recent bones, such as those from Igues de Bramarie, were found overlying karstic fill and were submitted to meteoric water leachings. Bones underlying or in karstic fill are generally packed in waterproof clay. Contrary to previously pub series, ages are time scattered and Ly-1294 is as old as most samples from Le Causse de Martel sites: Ly-1225, below, and Causse de Martel series, below and R, 1976, v 18, p 66-67 (Evin et al, 1980).

\section{Causse de Martel series, Lot and Corrèze}

Bones from various sp from fills of several aven, holes or grottos scattered on karstified calcareous plateau Causse de Martel, between Brive bassin and Dordogne $\mathrm{R}$ valley. Coll during paleontol excavation (Ly-1225) or during survey of paleontol sites.

\section{Ly-1293. Grange Cournille, Saint-Cernin de Larche, Corrèze

Bones (Bovidae, Equidae) filled Grange Cournille grotto, near SaintCernin de Larche, Corrèze (45 $6^{\prime} \mathrm{N}, 1^{\circ} 25^{\prime} \mathrm{E}$ ). Coll 1974 and subm 1975.

Ly-1574. Grotte Linoire, Turenne, Corrèze

$1420 \pm 220$

Bones of small sp from wastes of excavation in Linoire grotto, near Turenne, Corrèze $\left(45^{\circ} 03^{\prime} \mathrm{N}, 1^{\circ} 35^{\prime} \mathrm{E}\right), 1 / 2$ diluted sample. Coll 1974 and subm 1975.

\section{Ly-1575. Pech de l'Ajasse, Gignac, Lot}

\section{6,200}

$$
+\mathbf{1 3 0 0}
$$

Bones (Rangifer tatandus \& micro fauna) from base of Le Pech de $l^{\prime} A j a s s e$ aven, near Gignac, Lot $\left(44^{\circ} 58^{\prime} \mathrm{N}, 1^{\circ} 29^{\prime} \mathrm{E}\right), 1 / 10$ very diluted 
sample. Coll 1974 and subm 1975. Comment (MP): despite thick concretions on bones and large statistical margins, date is youngest for Würmian sites of Causse de Martel plateau and is, then, contemporaneous with many samples from Causse de Gramat plateau, above and R, 1975, v 17, p 13.

\section{Ly-1225. Siréjol, Couche très profonde,} Gignac, Lot

Bones (Bovidae) from lowest filling layer of Siréjol grotto, near Gignac, Lot, (44 $\left.59^{\prime} \mathrm{N}, 1^{\circ} 29^{\prime} \mathrm{E}\right)$. Coll 1975 and subm 1976. Comment (MP): perfectly confirms 2 previous measurements (Ly-614 and -767), of which average is $30,100 \pm 1100$, from upper layers of site fill which is then homogeneous in time $(\mathrm{R}, 1976, \mathrm{v} 18, \mathrm{p} 67)$. Three dates may be compared to results from Jaurens site (R, 1976, v 18, p 66; Evin et al, 1980).

General Comment (MP): as in series above, amount of organic content seems independent of absolute age of bones, and is more correlated with burial process.

\section{Ly-1177. Locus 3 de la Falaise, Vergisson, Saône et}

\section{Loire}

$28,680 \pm 660$

Bones of various sp (Bovidae, Equidae, Rodentia, Hyaenidae) from fill of fissure, called Locus 3, in calcareous cliff of Vergisson, Saône et Loire (46 $18^{\prime} \mathrm{N}, 4^{\circ} 42^{\prime} \mathrm{E}$ ). Coll 1974 and subm 1977 by M Philippe. Two neighboring fissures, Locus 1 and 2, are prehistoric sites in which were found Homo neandertalensis remains. Comment (MP): no systematic excavation was made to establish contemporaneity between dated fauna and Mousterian industry or human fossils.

\section{La Sartanette series, Remoulins, Gard}

Bones from 3 levels in deepest room, called "Couloir des Trépassés" of La Sartanette grotto, near Remoulins, Gard (43 $\left.56^{\prime} \mathrm{N}, 4^{\circ} 32^{\prime} \mathrm{E}\right)$ (Bonnet et al, 1946) Coll 1941 by A Bonnet and J du Cailar, preserved in Nîmes Mus and subm 1974 by A Bonnet, Nîmes. Because of low organic content all samples were measured in small detectors after dilutions.

Ly-1589. La Sartanette Couche $Z$

$4720 \pm 110$

Human bones from Layer $\mathrm{Z}$ overlying stalagmitic Floor $\mathrm{T}$, assoc with ceramic industry attributed to Early Bronze age. Comment (AB): too old for assumed assoc industry but makes sepulture contemporaneous with other Late Neolithic sepultures of same type with trepanned human skulls. In another part of grotto were found somewhat younger ages for a Late Neolithic industry of Chalcolithic-Ferrières type (Bonnet et al, 1973).

Ly-1590. La Sartanette, Couche $\mathbf{T}$

$21,900 \pm 1500$

Bones (Capra ibex) embedded in stalagmitic cover assumed from Layer $\mathrm{T}$ to be from Late Würm period, 3/4 diluted sample. Comment (AB): indicates end of Würm III, climatic phase of which cold climate 
is compatible with stalagmitic formation. Within statistics it may be contemporary with Ly-1591, below, from underlying Level P.

\section{Ly-1591. La Sartanette, Couche $P \quad 22,700 \pm 1700$}

Bones (Ursus spealeus) from Layer P, underlying stalagmitic Floor T, 3/4 diluted sample. Comment (AB): fauna (Ursus spelaeus) found in European grottos from Rumania to Spain were generally assumed from Würm I or Würm II glacial periods, such as in Prélétang grotto: Ly-167: older than 32,000 вр (R, 1971, v 13, p 45). Present results indicate Würm III agrees with similar fauna at Arlay, Jura: Ly-498/499: 25,720 \pm 700 (R, 1973, v 15, p 520).

\section{Ly-1597. Gouffre d'Abdala, Bagnères de Bigorre, Hautes Pyrénées}

Bones from clay fill of fissure presently filled in deep gallery of $\mathrm{Ab}$ dala gulf, near Bagnères de Bigorre, Hautes Pyrénées. $\left(43^{\circ} 05^{\prime} \mathrm{N}, 0^{\circ} 09^{\prime}\right.$ E). Coll 1967 and subm 1976 by A Clot, Bordères sur Echez. Assoc fauna contains a large bovine (maybe bison), a deer and a large hamster, found only once before in Middle Paleolithic site at Fontechevade, Charente. Comment (AC): as expected, date suggests Würm II is min so that fauna may be contemporaneous with Fontechavade site.

\section{Samples from fluviatile sediments}

\section{Ly-1100. Damerey, Saône et Loire}

$1930 \pm 300$

Small amount of bones from $2.5 \mathrm{~m}$ depth in drainage ditch in La Saône R alluvium at Damerey Saône et Loire $\left(46^{\circ} 51^{\prime} \mathrm{N}, 4^{\circ} 58^{\prime} \mathrm{E}\right)$. Coll 1975 by R Fleury, Bur recherches Geol Min, Orléans, and subm 1975 by A Marcé; 1/10 very diluted sample. Comment (RF): younger than expected considering burial depth of bones that may have been deposited during exceptional flood of La Saône R.

Ly-1553. Source 1, Bagnols les Bains, Lozère $\quad 1490 \pm 130$

Wood from frame of ancient catchment of thermal waters at well called "Source 1" at Bagnols les Bains, Lozère (44 $\left.30^{\prime} \mathrm{N}, 3^{\circ} 37^{\prime} \mathrm{E}\right)$. Coll 1977 by J J Risler, Bur recherches Geol Min Clermont-Ferrand and subm 1977 by A Marcé. Coll to determine age of 1st use of site. Comment (JJR): as expected, shows that catchment was 1st made during Roman time and may have been restored at end of this period.

\section{Ly-1552. Bois de Laives, Laives, Saône et Loire $\quad 3500 \pm 110$}

Wood from gravel quarry Le Bois de Laives, near Laives, Saône et Loire $\left(46^{\circ} 30^{\prime} \mathrm{N}, 4^{\circ} 49^{\prime} \mathrm{E}\right)$. Coll 1977 by R Fleury, and subm 1977 by A Marcé. Comes from same level as a previously dated wood: Ly-461: $5380 \pm 380(\mathrm{R}, 1973, \mathrm{v} 15, \mathrm{p} 136)$. Level lies between fine and coarse alluvium of La Grosne R. Comment (RF): agrees with previous date and gives approx value to accumulation rate of vegetal horizons and alluvium in La Saône R, tributary of which is La Grosne R. 
Barrage des Beaumes series, Saint-André d'Embrun Hautes Alpes

Wood from several morainic layers lying on left bank of Durance R, discovered in exploratory pit made to study dam settlement at Les Beaumes near Saint-André d'Embrun, Hautes Alpes (44 $24^{\prime}$ N, $6^{\circ} 31^{\prime} \mathrm{E}$ ). Coll and subm 1977 by M Giafferi, Geol Dept, Electricité de France, Paris.

Ly-1584. Les Beaumes 1

$3080 \pm 140$

Wood from $4.6 \mathrm{~m}$ depth.

Ly-1585. Les Beaumes 2

$2860 \pm 230$

Wood from $4.6 \mathrm{~m}$ depth, $5 / 6$ diluted sample.

Ly-1586. Les Beaumes 3

$2920 \pm 110$

Wood from $5.6 \mathrm{~m}$ depth.

General Comment (MG): three dates statistically yield same age and indicate rapid deposition.

Ly-1609. La Ratissou, Sablons, Isère

$2880 \pm 130$

Fragment of oak trunk found at $5 \mathrm{~m}$ depth on left bank of Rhône $\mathrm{R}$ in main channel at Ratissou, near Sablons, Isère $\left(45^{\circ} 20^{\prime} \mathrm{N}, 4^{\circ} 46^{\prime} \mathrm{E}\right)$. Coll and subm 1976 by $\mathrm{G}$ Chapotat, Centre recherches archeol Vienne. Comment (GC): dates youngest alluvium of Rhône $\mathrm{R}$ in site where Salaise series, below dates lowest terraces.

Villa San Maria, series, Chieti, Abruzzi, Italia

Wood from 2 levels of boring at Villa San Maria, near Chieti, Abruzzi, Italy $\left(41^{\circ} 57^{\prime} \mathrm{N}, 14^{\circ} 22^{\prime} \mathrm{E}\right)$. Coll by M Spilotro and subm 1974 by $\mathrm{G} S \mathrm{~S}$ Tazioli, Inst Geol Appl Geotech, Univ Bari.

Ly-1011. Villa San Maria A

$3990 \pm 120$

From 5.5m depth

Ly-1012. Villa San Maria B

$5240 \pm 120$

From $12.5 \mathrm{~m}$ depth.

General Comment (GST): dates landslide phenomena that embedded woods in fluvio-lacustrine formation.

Nuovo Porto di Gioiatauro, Reggio di Calabria, Calabria, Italia

Lignite from 2 neighboring borings at Nuovo Porto di Gioiatauro, near Reggio di Calabria, Calabria, Italy ( $38^{\circ} 28^{\prime} \mathrm{N}, 15^{\circ} 55^{\prime} \mathrm{E}$ ). Coll 1977 by A Guericchio and G Melidoro and subm 1977 by $G$ Melidoro, Ist Geotech, Univ Bari.

Ly-1665. Nuovo Porto di Gioiatauro L

$3870 \pm 430$

Small amount of material from $42 \mathrm{~m}$ depth in boring $\mathrm{L}, 1 / 5$ diluted sample. 
Ly-1666. Nuovo Porto di Gioiatauro $H$

$4000 \pm 160$

From $30 \mathrm{~m}$ depth in Boring $\mathrm{H}$.

General Comment (GM): as expected, both dates yield similar Holocene age to fluviatile formation in which they were embedded and show rapid sedimentation rate.

\section{Les Vollaires series, Lazer, Hautes Alpes}

Lignite from 3 levels of fluvio-lacustrian formation, outcropping on side of Le Clapier small $\mathrm{R}$ at Les Vollaires, near Lazer, Hautes Alpes $\left(44^{\circ} 21^{\prime} \mathrm{N}, 5^{\circ} 47^{\prime} \mathrm{E}\right)$. Coll and subm by G Monjuvent, Inst Dolomieu, Grenoble. Stratigraphic series is $10 \mathrm{~m}$ thick and has 14 layers of which 9 are lignite and 3 tufa. Pollen diagram studied by J L de Beaulieu.

\section{Ly-1329. Les Vollaires 14}

$5680 \pm 160$

From upper layer.

\section{Ly-1327. Les Vollaires 5}

$$
6870 \pm 180
$$

From layer in middle of tufa in central part of series.

Ly-1328. Les Vollaires 1

$12,250 \pm 430$

From lowest layer with organic matter, $5 / 6$ diluted sample.

General Comment (GM and JL de B): pollen diagram indicates Atlantic period for tufa embedding Ly-1627, agreeing perfectly with date. Despite their scarcity, pollen from lowest layer implies more temperate climate than generally assumed for late glacial climatic phase indicated by Ly1328. As expected, all values attribute Late Würm or Holocene age for lowest level of glacier of Saint-Genis Mt. Date between Ly-1328 and -1327 was previously obtained in similar series made nearby in Les Barbiers small R valley, near Lazer: Ly-555: $9250 \pm 190$ (R, 1973, v 15, p 516). Both series assoc with slimes overlying lowest terrace of Le Buech R.

\section{Ly-1704. La Borde, Joze, Puy de Dôme $\quad 7020 \pm 180$}

Tree trunk interstratified in pebble formation that constitutes lowest terrace of Allier R at La Borde, near Joze, Puy de Dôme $\left(45^{\circ} 51^{\prime} \mathrm{N}\right.$, $3^{\circ} 18^{\prime} \mathrm{E}$ ) (Daugas et al, 1978). Coll and subm 1978 by J P Daugas, Dir Ant Préhist, Auvergne Clermont-Ferrand and $\mathrm{J} P$ Raynal, Inst Quat Univ, Bordeaux. Comment (JP and JPR): peat layer was previously found near site and dated: Sa-103: 13,500 \pm 450 (R, 1965, v 7, p 241). Depth of this last sample was $14 \mathrm{~m}$; it was at about same relative alt above present channel of Allier R, as Ly-1704. Thus comparison of both dates supports hypothesis of Holocene tectonic up or down motions which involved recent filling and deepening phases in $\mathrm{E}$ part of Grande Limagne plain.

\section{Chonas series, La Terrasse, Isère}

Wood from several levels of Isère $\mathrm{R}$ alluvia in sand-pit at Chonas, near La Terrasse, Isère $\left(45^{\circ} 23^{\prime} \mathrm{N}, 5^{\circ} 55^{\prime} \mathrm{E}\right)$. Coll 1975 by C Hannss, Inst Geog, Univ Tübingen, and F Serre and C Goeury, Lab Bot et Palynol, Univ Aix-Marseille; subm 1977 by F Serre. 
Ly-1648. Chonas G II 1

$1040 \pm 150$

Indeterminable wood with diffuse pores, from pit base, 11.5 and $8.5 \mathrm{~m}$ below ground surface.

\section{Ly-1649. Chonas G II 4}

$4970 \pm 170$

Fragment of Quercus pubescens trunk from an unknown level in pit.

\section{Ly-1647. Chonas G II 3}

$11,520 \pm 260$

Wood (cf Pinus sylvestris) from same level as Ly-1648.

General Comment (FS): Ly-1647 supports unpub Heidelberg lab result: $11,850 \pm 100$ from same pit. Other results from neighboring pits also agree (Hannss, 1977). Ly-1648 shows disturbance due to quarrying, Ly-1649 fits with all other values in surrounding sites.

\section{Ly-1319. Graffen Weiher, Engenthal, Bas Rhin $\quad 10,580 \pm \mathbf{2 7 0}$}

Peaty sand from 5.2 to $5.3 \mathrm{~m}$ depth of boring in peat bog at Graffen Weiher, near Engenthal, Bas Rhin (48 $\left.38^{\prime} \mathrm{N}, 7^{\circ} 18^{\prime} \mathrm{E}\right)$. Coll 1976 by M Menillet, Bur recherches Geol Min, Orléans, and subm 1976 by A Marcé. Pollen diagram studied by G Farjanel, Bur recherches Geol Orléans. Comment (GF): pollen diagram at level indicates large extension of Betula, decrease of Pinus, and may correspond to Late Dryas period as implied by date.

\section{Aéroport Nice-Côte d'Azur series, Nice, Alpes Maritimes}

Samples from 3 levels of Core S Q 613 coll by boring in Le Var R alluvia in planned extension zone of Nice-Côte d'Azur airport, near Nice, Alpes Maritimes $\left(43^{\circ} 39^{\prime} \mathrm{N}, 7^{\circ} 12^{\prime} \mathrm{E}\right)$. Coll by Exploration Soc and subm by A Marcé.

Ly-1517. Nice Côte d'Azur, SQ 613, 32.7m

$6750 \pm 410$

Small bit of charcoal from $32.7 \mathrm{~m}$ depth, $8 / 30$ very diluted sample.

Ly-1518. Nice Côte d'Azur, SQ 613, 67.6m

$11,460 \pm 520$

Black clay from $67.6 \mathrm{~m}$ depth, $1 / 3$ diluted sample.

Ly-1519. Nice Côte d'Azur, SQ 613, 69.5m $12,760 \pm 710$ sample.

Black clay with some charcoal bits from $69.5 \mathrm{~m}$ depth, $1 / 5$ diluted

General Comment (AM): despite large counting error dates make it possible to estimate rapidity of recent Var R alluviation.

\section{Salaise sur Sanne series, Isère}

Bones from alluvium of 2 terraces of Rhône $\mathrm{R}$ near Salaise sur Sanne, Isère. Coll 1976 by G Mabilon, Le Péage de Roussillon and subm by $\mathrm{G}$ Chapotat.

Ly-1689. Les Blaches, Salaise sur Sanne

$14,110 \pm 620$

Equus femur and indeterminable humerus from ca 15 to $18 \mathrm{~m}$ depth

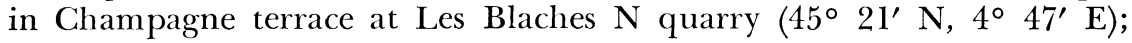
$1 / 3$ diluted sample. 
Ly-1690. Le Stade, Salaise sur Sanne

$20,370 \pm 460$

Fragment of Elephas primigenius humerus from $17 \mathrm{~m}$ depth in SaintRambert d'Albon terrace at Le Stade quarry $\left(45^{\circ} 21^{\prime} \mathrm{N}, 4^{\circ} 47^{\prime} \mathrm{E}\right)$.

General Comment (GC): Ly-1690 confirms -360: 18,800 \pm 490 (R, 1973, $\mathrm{v} 15, \mathrm{p} 138$ ) from same terrace $5 \mathrm{~km}$ upstream and assumed Late Würmian age of Saint-Rambert d'Albon terrace (David et al, 1972). Ly-1689 is youngest date obtained for Rhône terrace system (Chapotat et al, 1980).

\section{Ly-1587. Le Pont de Mirabeau, Saint-Paul lès} Durance, Bouches du Rhône

$$
+\mathbf{5 0 0 0}
$$

$\mathbf{2 6 , 5 5 0}$

Small charcoal bits found scattered in lithochrome colluvium interstratified in loess on left bank of Durance $\mathrm{R}$ at Pont de Mirabeau, near Saint-Paul lès Durance, Bouches du Rhône $\left(43^{\circ} 41^{\prime} \mathrm{N}, 5^{\circ} 30^{\prime} \mathrm{E}\right)$. Coll and subm 1974 by $\mathrm{P}$ Ambert, Inst Geog, Univ Aix en Provence; 1/2 diluted sample, measurement in proportional counters. Comment (PA): despite large counting error, date comparable with 2 previously pub results from similar stratigraphic series at Vautubière in same region: Ly769: $31,900+1900\left(\mathrm{R}, 1975, \mathrm{v} 17, \mathrm{p}\right.$ 9) and Ly-1002: $30,100 \begin{array}{l}+3400 \\ -2600\end{array}$ $(\mathrm{R}, 1976$, v 18, p 69). This agreement between 3 values makes questionable currently accepted chronology of slope deposits, which has been attributed to late interglacial in Provence (Ambert et al, 1974).

\section{L'Amourette series, Mens, Isère}

Woods from several level of series of torrential sediments at l'Amourette, near Mens, Isère $\left(44^{\circ} 48^{\prime} \mathrm{N}, 5^{\circ} 43^{\prime} \mathrm{E}\right)$. Coll and subm 1975 by M Archambault, Inst Etudes Ligériennes, Univ Orléans. Because very old ages of samples were expected, pyrophosphate treatment was lengthened to remove contamination.

Ly-1033. L'Amourette 2

From $42 \mathrm{~m}$ depth in $\mathrm{W}$ part of series. Counting of only $3 \mathrm{ml}$ benzene.

\section{Ly-1184. L'Amourette 6}

From $9 \mathrm{~m}$ depth: counting of $10 \mathrm{ml}$ benzene.

\section{Ly-1322. L'Amourette 5}

From $11 \mathrm{~m}$ depth: counting of $10 \mathrm{ml}$ benzene.

\section{Ly-1321. L'Amourette 3}

From $36 \mathrm{~m}$ depth: counting of $10 \mathrm{ml}$ benzene prepare tained by combustion of pyrolyzation gas. 
Same as Ly-1321 but $10 \mathrm{ml}$ benzene from sample combustion after pyrolization.

General Comment (MA): compatible with pub Le Villard series (R, 1978 , v 20, p 33). Should attribute Würm II age to sampled series which should be then contemporaneous with max advance of Isère glacier which formed Le Triève lake. Like Villard series, however pollen analysis indicates temperature climate which is somehow surprising during Würm II period.

Ly-1551. Forêt de Chaux, Falletans, Jura

$>\mathbf{3 0 , 0 0 0}$

Peaty lignite from $7.6 \mathrm{~m}$ depth in boring in superficial formations of Chaux forest, near Falletans, Jura $\left(47^{\circ} 03^{\prime} \mathrm{N}, 5^{\circ} 44^{\prime} \mathrm{E}\right)$. Coll 1976 by Y Kerien, Bur recherches Geol Min, Lyon, and subm 1976 by A Marcé. Comment (YK): as lignite horizon overlies several different formations, it might be assumed, with lack of fauna or pollen data, either very recent or coming from the Pliocene-Pleistocene limit, like other similar formations in region. Date rather supports the last hypothesis.

\section{E. Samples from various continental sediments}

\section{Chavannes series, La Thuile, Aosta, Italia}

Woods found in rocks falls at alt ca $1900 \mathrm{~m}$ in Chavannes small $\mathrm{R}$ valley, near La Thuile, Aoste, Italy $\left(45^{\circ} 44^{\prime} \mathrm{N}, 6^{\circ} 54^{\prime} \mathrm{E}\right)$. Coll 1975 by A Cerutti and subm 1976 by R Vivian, Inst Geog, Grenoble. Woods were uprooted by rock fall from Ciavaretta mt slope at ca alt $2100 \mathrm{~m}$. At present, very large trees cannot grow at high alts in valley. Growth period of dated trees is assumed to be before Little Glacial age, cold climatic phase that began approx in the 16th century and shifted timber line down.

\section{Ly-1617. Chavannes 1}

$170 \pm 130$

Fragment of Larix.

\section{Ly-1618. Chavannes 2}

$450 \pm 140$

Fragment of Pinus.

General Comment (RV): Ly-1618 agrees with hypothesis as it probably grew ca AD 1500. Ly-1617 is much younger than expected and should correspond to uplift of timber line after Little Glacial age, an hypothesis which remains very questionable.

\section{Ly-1655. Glacier du Chardon, La Bérarde, Savoie $\quad 560 \pm 120$}

Fragments of tree trunk from sediments lying on Le Chardon glacier at alt $2500 \mathrm{~m}$ at La Bérarde, near Saint-Christophe en Oisans, Savoie $\left(44^{\circ} 54^{\prime} \mathrm{N}, 6^{\circ} 18^{\prime} \mathrm{E}\right)$. Coll 1976 by $\mathrm{R}$ Lambert and subm 1977 by $\mathrm{R}$ Vivian. Wood probably comes from rock falls of lateral moraine that was covered by forest before Little Glacial age. Comment (RV): date is ca AD 1390, ie, before beginning of last cold climatic phase. Agrees with Ly- 
1618, above, and with previous measurement of another wood from front of same glacier: Ly-280: $750 \pm 130$ (R, 1973, v 15, p 135; Vivian, 1975).

\section{Ly-1219. Les Eymards, Lans en Vercors, Isère $\quad 860 \pm 130$}

Charcoal from assumed fossil soil at $150 \mathrm{~cm}$ depth at Les Eymards near Lans en Vercors, Isère $\left(45^{\circ} 6^{\prime} \mathrm{N}, 5^{\circ} 34^{\prime} \mathrm{E}\right)$. Coll and subm 1974 by G Monjuvent. Comment (GM): disagrees with expected age. Despite fossil aspect and depth, soil is recent and was probably covered by superficial slope deposits.

\section{Ly-1656. Corbassière, Fionnay, Valais, Suisse $\quad 4080 \pm 150$}

Fragment of tree trunk from channel of Corbassière, torrent at alt $2150 \mathrm{~m}, 150 \mathrm{~m}$ downstream of tongue of Corbassière glacier, near Fionnay, Valais, Switzerland $\left(46^{\circ} 02^{\prime} \mathrm{N}, 7^{\circ} 18^{\prime} \mathrm{E}\right)$. Coll 1976 by M Willaud, Soc Forces motrices Mauvoisin, Sion, and subm by R Vivian. Comment (RV): although nothing is known of growth place of tree, as it was found in torrent alluvium, date aligns it with other dated tree trunks from neighboring glacier Ferpècle, such as Ly-685: $3360 \pm 230$ or Ly-683: $5340 \pm$ 250 (R, 1975, v 17, p 7-8; Bezinge, 1974).

\section{Ly-1060. Saint-Bauzile, Ardèche}

Lignitic debris from diatomitic layer outcropping in quarry near Saint-Bauzile, Ardèche (44 $40^{\prime} \mathrm{N}, 4^{\circ} 40^{\prime} \mathrm{E}$ ). Coll and subm 1975 by $\mathrm{P}$ Délétie, Geol Dept Electricité de France, Paris. Layer assoc with recent basaltic flows, $1978 \mathrm{~K} /$ ar dating of which gave ca $4.1 \mathrm{MA}$, and confirmed no radiocarbon activity of sample.

\section{F. Samples from marine and lagoonal sediments}

\section{Ly-1265. Marais de la Fosse, Saint-Gilles du Gard $3820 \pm 140$}

Shells (Cardium edule) picked up on surface of La Fosse coastal peat bog, near Saint-Gilles du Gard, Gard (43 $37^{\prime}$ N, $4^{\circ} 14^{\prime}$ E). Coll 1976 by F Bazile, Vauvert, and A L'Homer and subm 1976 by A Marcé. Comment (FB and $\mathrm{AL}$ ): dates closing of presently filled lagoon in Rhône $\mathrm{R}$ delta and fits with 2 other results from another lagoon in delta, MC-1161: $4190 \pm 70$ and MC-1162: $4160 \pm 100$ (Bazile, 1976).

\section{Ly-1159. Le Relais, Fos sur Mer, Bouches du Rhône $5890 \pm 200$}

Large shells coll on offshore bar at alt $-1.5 \mathrm{~m}$ at pumping sta Le Relais near Fos sur Mer, Bouches du Rhône $\left(43^{\circ} 28^{\prime}\right.$ N, $4^{\circ} 49^{\prime}$ E). Coll 1976 by A L'Homer and subm 1976 by A Marcé. Comment (AL): as in W part of Le Rhône $\mathrm{R}$ delta a contemporaneous offshore bar (see, Ly1514 , below) is at alt $+1.5 \mathrm{~m}$; difference between both dates shows importance of subsidence movement that occurs in central part of Rhône $R$ delta. 


\section{Le Grau du Roi series, Hérault and Gard}

Marine shells from offshore bars, approx parallel to present coast in W part of Le Rhône R delta. Coll 1977 by A L'Homer and subm 1977 by A Marcé.

\section{Ly-1514. Le Grau du Roi 25647, Aigues-}

\section{Mortes, Gard}

From youngest offshore bar, $1 \mathrm{~km} \mathrm{~W}$ Aigues-Mortes, Gard $\left(43^{\circ} 45^{\prime} \mathrm{N}\right.$, $\left.4^{\circ} 10^{\prime} \mathrm{E}\right)$.

Ly-1512. Le Grau du Roi 25645, Le Grand Travers, Hérault

$6080 \pm 170$

From youngest offshore bar, between Maugio pond and sea, at Le Grand Travers $\left(43^{\circ} 44^{\prime} \mathrm{N}, 4^{\circ} 03^{\prime} \mathrm{E}\right)$.

\section{Ly-1513. Le Grau du Roi 25646, Bergerie de} Haute Plage, Hérault

$6660 \pm 170$

From intermediate offshore bar, at La Bergerie de Haute Plage, near La Grande Motte, Hérault $\left(43^{\circ} 45^{\prime} \mathrm{N}, 4^{\circ} 05^{\prime} \mathrm{E}\right)$.

\section{Ly-1511. Le Grau du Roi 25644, Le Petit Travers, Hérault}

From oldest offshore bar between Maugio pond and sea, at Le Petit Travers, Herault $\left(43^{\circ} 43^{\prime} \mathrm{N}, 4^{\circ} 02^{\prime} \mathrm{E}\right)$.

General Comment (AL): all results agree with series of MC lab dates on shells from other sampling points on same bars between Maguelonne and Aigues-Mortes (Bazile, 1974). Both series elucidate emerging sequence of recent ages of parallel bars according to proximity to present sea coast, $i e$, land advancement in that part of Rhône delta.

\section{Ile des Madeleines series, Sénégal}

Marine shells from 2 places on small island Les Madeleines, W Dakar, Sénégal $\left(14^{\circ} 34^{\prime} \mathrm{N}, 17^{\circ} 29^{\prime} \mathrm{W}\right)$. Coll and subm 1978 by P Elouard, Geol Dept, Univ Lyon.

\section{Ly-1671. Plage de l'Ile des Madeleines}

$$
\delta^{14} \mathbf{C}=+\mathbf{0 . 5 \%} \pm \mathbf{1 . 5}
$$

Shells (Patella safiana) from beach at alt $+2 \mathrm{~m}$. Comment (PE): proves that shells are recent storm sediments and are not sediments of assumed raised beach.

Ly-1670. Sommet de l'Ile des Madeleines $1130 \pm 130$

Shells (Thais haemastoma) from kitchen midden at top of island. Comment (PE): confirms human occupation of island at same period in which kitchen midden of Le Fadiout or Le Salaun region was built (see, eg, Bangaléré series: R, 1975, v 17, p 13).

\section{Rao and Gandon series, Sénégal}

Shells (Arca senelis) from marine terraces near Rao $\left(15^{\circ} 56^{\prime} \mathrm{N}, 16^{\circ}\right.$ $\left.26^{\prime} \mathrm{W}\right)$ and Gandon $\left(15^{\circ} 57^{\prime} \mathrm{N}, 16^{\circ} 26^{\prime} \mathrm{W}\right)$ villages, near Saint-Louis, 
Sénégal. Coll 1973 by J Monteillet, Saint-Louis, and subm 1978 by $\mathbf{P}$ Elouard. Measurements made to complete previously pub results (R, 1976, v 18, p 69; Monteillet, 1974).

\section{Ly-1344. Rao R I A $4220 \pm 160$ \\ Ly-1347. Rao R I E \\ $\mathbf{4 5 8 0} \pm \mathbf{5 2 0}$} sample.

$4 / 30$ very diluted sample because of accidental loss of most of the

Ly-1346. Gandon G I C

$2 / 3$ diluted sample.

$5200 \pm 210$

Ly-1345. Gandon G I A

$1 / 2$ diluted sample.

$5670 \pm 240$

General Comment (PE): Ly-1344 and -1345 come from level that marks small transgressive oscillation during general regression following max of Nouakchottian transgression. They both confirm Ly-982: $4670 \pm 120$ and Ly-986: $4720 \pm 140$. Ly-1345 and -1346 mark max of Nouakchottian transgression and agree with previous dates for same event on same site Ly-983: $5250 \pm 120$, Ly-985: $5650 \pm 150$ and Ly-987: $5590 \pm 140$ and on numerous sites of W African coast (Elouard, 1968).

\section{Côte de l'Angola series, Angola}

Shells from marine terraces, lying behind present shore and attributed to Nouakchottian transgression, ca $6000 \mathrm{BP}$, because of alt and fauna. Coll 1974 by P Giresse and M Kouyoummtzakis, Univ Brazzaville, Congo, and subm 1975 by P Elouard.

\section{Ly-1271. Estrada de Catumbela

Shells (Arca senelis) from 7 to $10 \mathrm{~m}$ alt on Catumbela rd side $\left(12^{\circ}\right.$ $\left.28^{\prime} \mathrm{S}, 13^{\circ} 35^{\prime} \mathrm{E}\right)$.

\section{Ly-1273. Baia de Azal G K AN 2/57}

$+1700$

$$
-1400
$$

Shells (Arca senelis, Typonatinus fuscatus), from 10 to $12 \mathrm{~m}$ alt on Azal beach $\left(12^{\circ} 38^{\prime} \mathrm{S}, 13^{\circ} 15^{\prime} \mathrm{E}\right)$.

\section{Ly-1272. Estrada da Baia des Pipas G K AN 2/40 $\geqslant 31,400$} $\left.12^{\circ} 12^{\prime} \mathrm{E}\right)$.

Shells (Cardium rigens) from $15 \mathrm{~m}$ alt on Pipas beach $\mathrm{rd}\left(15^{\circ} 07^{\prime} \mathrm{S}\right.$,

General Comment (PE): series does not confirm expected Holocene age and indicates that terraces were probably formed during Inchirian transgression, ca 30,000 вP (Elouard \& Faure, 1967). 
II. ARCHAEOLOGIC SAMPLES

A. Historic and Protohistoric periods

Ly-1581. Saint-Cyr sur Rhône, Rhône

Skull from Grave 2 of an ancient cemetery, Saint-Cyr sur Rhône $\left(45^{\circ} 31^{\prime} \mathrm{N}, 4^{\circ} 50^{\prime} \mathrm{E}\right)$; coll and subm 1976 by $\mathrm{G}$ Chapotat. No assoc industry was found in grave which was dug in loess and surrounded by stones. Comment (GC): any age was expected; date shows that cemetery was used during Middle Age.

Ly-1626. Le Pusmin, Sarzeau, Morbihan $\quad 1250 \pm 150$

Fragment of a wooden beam from stud-work of ground level of Medieval house at Le Pusmin, near Sarzeau, Morbihan (47 $31^{\prime} \mathrm{N}, 2^{\circ} 48^{\prime}$ W). Coll and subm 1977 by P Gévin, Dept Geol, Univ Lyon. 9/10 diluted sample. Comment (PG): 1st story of house has large windows and is precisely dated by inscription on beam from AD 1568. Ly-1626 shows that lowest part of house with windows was built during Early Middle Age, agreeing with architectural style of popular houses from this period.

Ly-1667. Cimetière des Chouennes, Brens, Ain

$1340 \pm 240$

Human bones from ancient cemetery, "Burgonde", constituted of sepultures with small flag-stones at Les Chouennes, near Brens, Ain $\left(45^{\circ}\right.$ $42^{\prime}$ N, $5^{\circ} 41^{\prime}$ E). Coll and subm 1977 by R Vilain; Dept Geol, Univ Lyon. Bones lay in sandy sediment exposed to leaching by meteoric waters. Organic matter was badly preserved and samples were too diluted to be counted in small proportional detectors. Comment (RV): date, ca 4th to 6 th century, agrees with expected range of dates for such "Burgonde" cemetery.

Ly-1580. Sainte-Blandine, Vienne, Isère

$1720 \pm 110$

Human skull from ca $2 \mathrm{~m}$ depth in alluvia at foot of Sainte-Blandine hill at Vienne, Isère $\left(45^{\circ} 31^{\prime} \mathrm{N}, 4^{\circ} 53^{\prime} \mathrm{E}\right)$. Coll 1972 by M Eynaud and subm 1976 by G Chapotat, Centre Recherches Archeol, Vienne. Comment (GG): as bones were found near La Tène III site, expected age was 50 вс. Date rather indicates end of Roman period, during which boundary of Roman town was very close to sampling site.

Ly-1410. Grigny RH 83, Rhône

$2250 \pm 120$

Fragment of wooden (Pinus picea) handle of iron object, presumably a ploughshare, dredged from Rhône $R$ at Grigny, Rhône $\left(45^{\circ} 36^{\prime} \mathrm{N}\right.$, $4^{\circ} 47^{\prime} \mathrm{E}$ ). Coll 1972 and subm 1977 by $\mathrm{G}$ Chapotat. Comment (GC): agrees with other measurements from similar wooden handles of metal objects from same site ( $\mathrm{R}, 1976, \mathrm{v}$ 18, p 71 ) ranging from Middle Bronze to La Tène III periods (Chapotat et al, 1978).

\section{Agay and Bataignerseries, Var and Alpes Maritimes series}

Human bones found on sea bottom, very close to 2 wrecks submerged near Mediterranean seashore. Artifacts assoc with wrecks date 
from ca AD 950 (Arnaud et al, 1978). Subm 1977 by G and S Arnaud, Paleo-anthropology Lab, Draguignan.

\section{Ly-1469. Agay, Var}

$1790 \pm 110$

From $-50 \mathrm{~m}$ alt, in Agay bay, near Agay, $\operatorname{Var}\left(43^{\circ} 26^{\prime} \mathrm{N}, 6^{\circ} 5 \mathrm{l}^{\prime} \mathrm{E}\right)$. Coll 1968 by A Visquis.

\section{Ly-1471. Bataigner B, Cannes, Alpes Maritimes $1390 \pm 300$}

From $-54 \mathrm{~m}$ alt, $500 \mathrm{~m}$ E Sainte-Marguerite I. in Napoule bay near Cannes, Alpes Maritimes (43 $\left.31^{\prime} \mathrm{N}, 7^{\circ} 01^{\prime} \mathrm{E}\right)$. Coll 1974 by J P Joncheray; $5 / 6$ diluted sample.

\section{Ly-1472. Bataigner C, Cannes, Alpes Maritimes $1350 \pm 150$}

From another skeleton from same location as Ly-1471.

General Comment (GA \& SA): younger than expected by artifacts assoc with wrecks. Relationship between skeletons and ships is not well established, as many shipwrecks occurred in region for 2 millennia.

\section{Ly-1625. Le Parc, Yzeron, Rhône \\ $1700 \pm 200$}

Charcoal fragment from shallow ashy layer in meadow at Le Parc, near Yzeron, Rhône $\left(45^{\circ} 43^{\prime} \mathrm{N}, 4^{\circ} 36^{\prime} \mathrm{E}\right)$. Coll and subm 1977 by $\mathrm{L}$ Jeancolas, Tassin. 1/3 diluted sample. Site is shallow circular mound presumably starting point of Roman aqueduct supplying "Lugdunum", Roman city of Lyon. Comment: despite uncertainty, date confirms hypothesis of aqueduct origin.

Ly-1657. Saré Diouldé, IFAN 123, Koussanar, Sénégal $430 \pm 130$

Charcoal from $0.5 \mathrm{~m}$ depth under top of stoney funeral tumulus at Saré Dioudlé Koussanar IDist, Sénégal (14 $\left.7^{\prime} \mathrm{N}, 13^{\circ} 50^{\prime} \mathrm{W}\right)$. Coll 1977 by G Thilmans and subm 1977 by G Descamps, Inst Fondamental Afrique Noire, Dakar. This Megalithic Senegambian monument included ca 20 burials with only a few potsherds. Comment (CD): Senegambian megaliths are found in 3 regions. Date proves that those from $\mathrm{E}$ region are much younger than those from central (Tiekene Boussoura, Ly-1343, below) or W (Sine Ngayéne, Dak-201: $867 \pm 117$; R, 1977, v 19, p 161) regions.

\section{Ly-1343. Tiekene-Boussoura, IFAN 109, Koupentoum,} Sénégal

$1160 \pm 220$

Powder of black potsherds from $1 \mathrm{~m}$ depth in Megalithic Circle 4 of Tiekene-Boussara site, Koupentoum Dist, Sénégal $\left(14^{\circ} 00^{\prime} \mathrm{N}, 14^{\circ} 35^{\prime} \mathrm{W}\right)$. Coll 1975 by G Thilmans and subm 1976 by C Descamps (Thilmans \& Descamps, 1975). $1.2 \mathrm{~kg}$ of potsherds were powdered and burned to get 2/3 diluted sample. Comment (CD): agrees with other results from similar monuments at Kodian site: Dak-41: $1356 \pm 126$; Dak-54: $1212 \pm 125$; at Wassu site, Dak-2: $1200 \pm 110$ (Thilmans \& Descamps, 1974).

\section{Koumbi Saleh series, Timbedra, Mauritania}

Charcoal from several different places in Koumbi Saleh archaeol site, $55 \mathrm{~km}$ NE Timbedra, Mauritania $\left(15^{\circ} 46^{\prime} \mathrm{N}, 7^{\circ} 59^{\prime} \mathrm{W}\right)$. Site is prob- 
ably one of former capitals of ancient empire of Ghana (7th to 19th centuries). Site was excavated several times since 1913. Samples come from last excavation period $(1975,1976)$. Excavations were directed by S Robert, Inst Mauritanien recherches Sci, Nouakchott, helped by A Cross, French Center of French Embassy, Libreville; and S Berthier, Hist Dept, Univ Lyon II. SB I and SB II refs indicate samples from 2 neighboring excavations in 1975 and 1976 by S Berthier in SE part of town, near an old mosque. S Robert excavated here in 1975 and 1976 and got samples with SR II and SR III refs. Occupation of Koumbi Saleh site seems to have been continuous for at least 7 centuries, from about end of 7 th century to 15 th century. Stratigraphy of site could be divided in 3 important periods, each comprising 2 to 4 levels. Period of Levels I a/b may correspond to ancient pre-urban or to lst urban occupation from 7 th to 9 th centuries; period of Levels II a/b corresponds to 1 st important city from beginning of 9 th to 12 th centuries; period of Levels III a/b/c/d correspond to most recent occupation with recently well-preserved walls and house from 12 th to 15 th centuries.

\section{Ly-1525. Koumbi Saleh SB I 56}

$440 \pm 180$

From $335 \mathrm{~cm}$ depth, Level III/c; $1 / 2$ diluted sample.

Ly-1524. SB I 48

$\mathbf{5 5 0} \pm \mathbf{2 3 0}$

From $350 \mathrm{~cm}$ depth, Level III/c; $1 / 5$ diluted sample.

Ly-1526. SB I 73

$860 \pm 210$

From $410 \mathrm{~cm}$ depth, Level III/b; $1 / 3$ diluted sample.

Ly-1520. SB I 95

$590 \pm 120$

From $465 \mathrm{~cm}$ depth, Level III/a.

Ly-1521. SB II 15

$230 \pm 120$

From 255/260cm depth, Level III/d.

Ly-1341. SB II 46

From $395 / 400 \mathrm{~cm}$, Level III $/$ b; $1 / 2$ diluted sample.

$1000 \pm 150$

\section{Ly-1523. SR II 39}

$500 \pm 110$

From $340 / 350 \mathrm{~cm}$ depth, Level III $/ \mathrm{c}$.

Ly-1522. SR II 40

$500 \pm 120$

From $340 / 350 \mathrm{~cm}$ depth, Level III $/ \mathrm{c}$.

Ly-1610. SR II 41a

$1400 \pm 160$

From $350 \mathrm{~cm}$ depth, Level III/c; 5/6 diluted sample.

Ly-1792. SR II 41b

$1280 \pm 150$

From $350 \mathrm{~cm}$ depth, Level III/c.

Repeat of previous sample. Average of both $1340 \pm 100$.

Ly-1612. SR III 163

$940 \pm 120$

From $290 \mathrm{~cm}$ depth, Level III b/c. 
Ly-1615. SR III 177

$980 \pm 130$

From $340 \mathrm{~cm}$ depth, Level III/b.

Ly-1613. SR III 165

$1210 \pm 140$

From $360 \mathrm{~cm}$ depth, Level III a/b.

Ly-1614. SR III 170

$540 \pm 120$

From $355 / 360 \mathrm{~cm}$ depth, Level III $/$ b.

Ly-1616. SR III 196

$1290 \pm 130$

From $620 / 650 \mathrm{~cm}$ depth, Level I/c-II/a.

Ly-1611. SR III 152

$870 \pm 120$

From $630 \mathrm{~cm}$ depth, Level $\mathrm{Ib} / \mathrm{II} / \mathrm{a}$.

General Comment (SR): most results from excavation SB I, SB II and SR III (except Ly-1521, -1610, -1792) seem to connect hypothetical stratigraphy (Berthier, 1978) and previous measurements: Dak-156: $981 \pm$ 114 and Dak-157: $1122 \pm 125$ from Level Ia in 1972 excavation by A Cros and S Robert (R, 1977, v 19, p 162). Two results appear older than previously imagined: Ly-1526 and -1341. Ly-1792 check does not confirm eventual inversion between Ly-1611 and -1610 which was believed would explain discrepancy of both results. From excavation SR III only Ly-1611 and -1614 seem to conform obviously to other investigations. The other 4 dates seem too old without precise importance of divergence, particularly between Ly-1612 and -1615, for unknown reason (D Robert \& S Robert, 1979).

\section{Kandiama series, Velingara, Sénégal}

Charcoal from several places in Kandiama site, Velingara Dist, Sénégal $\left(13^{\circ} 10^{\prime} \mathrm{N}, 13^{\circ} 51^{\prime} \mathrm{W}\right)$. Coll and subm by J Girard, Univ Lyon. This enigmatic site is system of shallow intersecting galleries, filled by secondary lateritic sediments.

Ly-1312. Kandiama 2

Modern

$\delta^{14} \mathrm{C}=-1.7 \% \pm 2.1$

From base of gallery alpha. $5 / 6$ diluted sample. Coll and subm 1976 .

Ly-1313. Kandiama 3

Modern

From inside filling of gallery alpha. Coll and subm 1976.

$\delta^{14} \mathrm{C}=-\mathbf{2 . 0} \% \pm \mathbf{1 . 7}$

Ly-1156. Kandiama 1

$1540 \pm 180$

From gallery 5m deep. 1/2 diluted sample. Coll and subm 1975.

Ly-1780. Kandiama $C$

$490 \pm 160$

From base of filling of C gallery. Coll and subm 1978

Ly-1781. Kandiama $C^{\prime}$

$1050 \pm 170$

From base of inside filling of $\mathrm{C}^{\prime}$ Gallery. Coll and subm 1978. 
Ly-1782. Kandiama $C^{\prime \prime}$

From base or inside filling of $\mathrm{C}^{\prime \prime}$ gallery. $1 / 4$ diluted sample counted in proportional detector. Coll and subm 1978.

General Comment (JG): Ly-1312, -1313 , and -1780 prove that secondary materials entered galleries before and after excavations. Ly-1781, -1782, and -1156 agree with expected age, as oral tradition since 11th century mentions gallery habitation in region.

Ly-1604. Santourin, Billième, Savoie

$2240 \pm 260$

Small bits of charcoal from 4 places in archeol layer with poor ceramic industry. At $1.7 \mathrm{~m}$ depth near Megalithic monument (LagierBruno, 1973), called "La Pierre de Santourin" at Santourin, near Billième, Savoie $\left(45^{\circ} 48^{\prime}\right.$ N, $5^{\circ} 23^{\prime}$ E). Coll 1975 and 1976 by L LagierBruno, Yenne. Comment (LLB): indicates La Tène period and supports attribution of layer to temporary settlement of sheep-fold on site, which is, thus, independent of Megalithic monument.

Ly-1573. Vallée des Reines, Luxor, Egypt

$2490 \pm 250$

Fragment of human mummy from ancient excavation in Les Reines valley near Luxor, Egypt $\left(25^{\circ} 41^{\prime} \mathrm{N}, 32^{\circ} 28^{\prime} \mathrm{E}\right)$. Coll 1976 and subm 1977 by R Laurent, Villeurbanne. Comment (RL): despite poor preservation conditions and unscientific collection procedures, date proves mummy is authentic and may come from Late Empire epoch.

Dikili Tash series, Krinides, Kavala, Greece

Charcoal from several levels of Dikili Tash site, near Krinides, Kavala province, Greece $\left(41^{\circ} 00^{\prime} \mathrm{N}, 24^{\circ} 40^{\prime} \mathrm{E}\right)$. Coll and subm by $\mathrm{J}$ Deshayes, Univ Paris I.

Ly-1306. Dikili Tash C 75-2

$2870 \pm 370$

From Soil 2 in Boring $\mathrm{B}^{\prime} \mathrm{C}^{\prime}$. Coll and subm 1975; assoc with Late Bronze industry. Expected age: $1500 \mathrm{BC}$. Very, 8/30, diluted sample.

Ly-1063. Dikili Tash C 74-6

$3430 \pm 120$

From $1.5 \mathrm{~m}$ depth under remains of fallen Late Bronze wall. Coll and subm 1974. Expected age: ca 1500 Bc.

Ly-1304. Dikili Tash C 75-6

$2370 \pm 230$

From Soil 3 in Boring $\mathrm{A}^{\prime} \mathrm{B}^{\prime}$. Coll and subm 1975; assoc with industry attributed to end of Troie I culture. Expected age: са 2500 вс; $2 / 3$ diluted sample.

Ly-1305. Dikili Tash C 75-7

$5030 \pm 160$

From Soil 3 in Boring P 24. Coll and subm 1975, assoc with industries attributed to end of Troie I culture. Expected age: ca 2500 BC.

Ly-1061. Dikili Tash C 74-1

$6480 \pm 270$

From soil at $1 \mathrm{~m}$ depth. Coll and subm 1974. Assoc with industry of "Baden" culture. Expected age: са 3000 вс; 1/3 diluted sample. 
Ly-1602. Dikili Tash C 74-2

$3700 \pm 230$

From same soil as Ly-1061. Coll and subm 1975; 1/3 diluted sample. Measurement in proportional detector.

Ly-1064. Dikili Tash C 74-7

$6040 \pm 120$

From ditch at $1.75 \mathrm{~m}$ depth. Coll and subm 1974; assoc with some Chalcolithic potsherds. Expected age: 3500 вс or Expected age if from the beginning of Late Bronze level :3000 BC.

\section{Ly-1062. Dikili Tash C 74-5}

$6100 \pm 200$

From soil at $1.85 \mathrm{~m}$ depth. Coll and subm 1974, assoc with end of Chalcolithic industry. Expected age may agree with 2 unpub Gif dates: Gif-1425: $5750 \pm 140$ and Gif-1738: $5600 \pm 150.2 / 3$ diluted sample.

General Comment (JD): most results do not fit expected ages, especially Ly-1304 and -1602, which are much too young. Ly-1061 is much too old and does not agree with strat order, for unknown reason. Ly-1063 shows that Level 2 of site belongs to Late Bronze period, as confirmed by further excavations. Even taking into account its large statistical margin, Ly-1306 inexplicably remains younger than Ly-1063. Ly-1305 is a little older than 6 unpub Pennsylvania lab results: P-917-923: 2300 to 2450 BC. Ly-1064 demonstrates that the ditch is Chalcolithic and is a little older than previous results and Ly-1062.

\section{Pirak series, Baluchistan, Pakistan}

Charcoal from several levels of tell, $9 \mathrm{~m}$ high, at Pirak, near Sibi, Baluchistan, Pakistan $\left(29^{\circ} 30^{\prime} \mathrm{N}, 67^{\circ} 54^{\prime} \mathrm{E}\right)$. Coll by French Archaeol Mission of Indus; subm 1978 by J F Jarrige, Guimet Mus Paris (Jarrige \& Enault, 1976).

\section{Ly-1644. Pirak 5}

$1800 \pm 170$

From Layer 3 at 1.5m depth, Sq 3-O, Loc 88. Coll 1974. Assoc with mixed industry from Bronze and Iron ages Expected age: ca 900 BC.

Ly-1643. Pirak 4

$2970 \pm 140$

From Layer 8 at 2.5m depth, Sq 4-L, Loc 84. Coll 1974. Assoc with industry from beginning of Iron age. Expected age: ca 1000 BC.

Ly-1642. Pirak 3

$3150 \pm 150$

From Layer 34 at $6 \mathrm{~m}$ depth, Sq 3-I. Coll 1971. Assoc with industry from end of Bronze age. Expected age: ca 1400 BC.

Ly-1641. Pirak 2

$4080 \pm 290$

Form Layer $39 \mathrm{~N}$ at $8 \mathrm{~m}$ depth and $1 \mathrm{~m}$ above present plain level, $\mathrm{Sq}$ 3-I. Coll 1973. Assoc with Bronze age industry. Expected age: ca 1450 BC. $1 / 2$ diluted sample.

Ly-1640. Pirak 1

$3410 \pm 140$

From Layer 40 at $9 \mathrm{~m}$ depth and at present plain level, Sq 3-I, Loc 73. Coll 1973. Assoc with Bronze age industry. Expected age: ca 1550 вс. 
General Comment (JFJ): Ly-1644 is much younger than expected which may be due to contamination by recent roots or deep burrow holes in upper levels of tell. Ly-1641 is too old either because of statistical variation, or, more probably, because of intrusion of ashes from older occupation level, presently almost completely eroded. Three other results agree with expected values.

Ly-1409. La Madeleine des Albis, Penne, Tarn

$890 \pm 180$

Charcoal from a hearth at $0.25 \mathrm{~m}$ depth in large room of La Madeleine grotto near Penne, Tarn $\left(44^{\circ} 05^{\prime} \mathrm{N}, 1^{\circ} 43^{\prime} \mathrm{E}\right)$. Coll 1976 by $\mathrm{H}$ Bessac and subm by J Lautier, Albi. Assoc with mixed industries from several epochs of Bronze age period. Comment $(\mathrm{JL})$ : proves that sediment probably was redeposited in Middle age, as confirmed later by discovery of potsherds from $\mathrm{AD}$ era, in site border.

\section{Ly-1566. Hohlandsberg 76 L II, Wintzenheim, Haut-Rhîn}

Charcoal from soil at $0.8 \mathrm{~m}$ depth in alt habitat at Holandsberg,

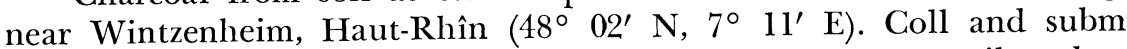
1976 by $S$ Plouin, Ingersheim. Industries found at site are attributed to Late Bronze II and III periods, but exact assoc of sample with either of these periods is uncertain. Comment (SP): dates occupation soil from early period: Late Bronze II agrees closely with Gsy-85: $3215 \pm 150(\mathrm{R}$, 1966, v 8, p 132) from another Late Bronze II site at Cronenbourg, BasRhîn. However, both dates are a little older than expected according to generally accepted chronology of Bronze age in region.

\section{Ouroux series, Ouroux sur Saône, Saône et Loire}

Samples from homogeneous archaeol level which is fire destroyed dwelling of riverside site of Ouroux, near Ouroux-sur-Saône, Saône et Loire $\left(46^{\circ} 43^{\prime} \mathrm{N}, 4^{\circ} 56^{\prime} \mathrm{N}\right)$. As site is presently submerged in La Saône $\mathrm{R}$, sample was coll 1973 by dredging and subm by L Bonnamour, Denon Mus, Châlon sur Saône. Late Bronze IIIb industry gives expected date ca 750 вс (Bonnamour, 1974).

Ly-1025. Ouroux, 38/52

$3110 \pm 110$

Charred wood, from beam; subm 1974.

Ly-1570. Ouroux 1

$2720 \pm 150$

Charcoal from twigs; subm 1976.

\section{Ly-1571. Ouroux 2}

$2710 \pm 130$

Charred twigs; subm 1976.

General Comment (LB): very old date of Ly-1025 is probably due to age of beam when used for dwelling construction. Dates from twigs agree perfectly with expected age. 


\section{B. Neolithic period}

Ly-1624. La Côte de Bar, Saint-Mihiel, Meuse

$3770 \pm 230$

Charcoal from upper level of Boring M2 in Shaft 2 at 1 end of Neolithic flint mine at La Côte de Bar, near Saint-Mihiel, Meuse $\left(48^{\circ}\right.$ $48^{\prime} \mathrm{N}, 5^{\circ} 31^{\prime} \mathrm{E}$ ). Coll 1976 by V Blouet and subm 1977 by C Guillaume, Dir Antiquités Préhist, Lorraine, Metz. Assoc with a Neolithic industry (may be Seine-Oise-Marne), 9/10 diluted sample Comment (CG): at other end of mine, 2 structures were previously dated: Ny-285: $4170 \pm$ 70 (R, 1974, v 16, p 122) and MC-573: $4060 \pm 50$ (unpub). Three dates, even with their maximal statistical margins, prove that mining lasted for only a short time (Guillaume, 1974).

\section{Le Trou des Fées series, Bayonville sur Mad, Meurthe et Moselle}

Charcoal from 1 level in Neolithic sepulchral grotto Le Trou des Fées, near Bayonville sur Mad, Meurthe et Moselle $\left(49^{\circ} 01^{\prime} \mathrm{N}, 5^{\circ} 58^{\prime} \mathrm{E}\right)$. Coll by V Blouet and subm 1977 by C Guillaume.

Ly-1622. Bayonville sur Mad, 1/76

From Pit X2. Coll 1976; 3/5 diluted sample.

$4170 \pm 200$

Ly-1623. Bayonville sur Mad, 1/77

From Hearth 3, in W gallery. Coll 1977.

General Comment (CG): both dates are very close to each other and agree with expected age for this type of Late Neolithic monument. In nearby Noveant sur Moselle site, 2 sepultures assoc with same industry were dated by Nancy at $4520 \pm 70$ (unpub) for Sepulture 2 and Ny-297: $4140 \pm 70$ for Sepulture 1 (Guillaume, 1978).

\section{Conjux series, Savoie}

Wood from several levels of lake margin site, discovered in boring lake sediments in N part of Le Bourget lake, at Conjux, Savoie $\left(45^{\circ} 47^{\prime}\right.$ N, $5^{\circ} 49^{\prime}$ E). Coll 1975 by R Castel, Aix les Bains, and subm 1975 by R Laurent, Villeurbanne. Boring showed 2 intact superimposed occupation levels, in sta to $S$ and separated from formerly excavated lake margin site.

\section{Ly-1326. Conjux 4}

Fragment of pile from house of upper level at $0.6 \mathrm{~m}$ depth.

$$
2870 \pm 140
$$

Ly-1325. Conjux 3

Fragment of pile from house of lower level at $1.5 \mathrm{~m}$ depth.

\section{Ly-1324. Conjux 2}

Fragment of tree branches from partition between 2 piles of house of lower level at $1.9 \mathrm{~m}$ depth.

\section{Ly-1323. Conjux 1}

Fragment of wooden joist sustaining floor of house of lower level at $1.9 \mathrm{~m}$ depth. 
General Comment (RL): agrees with expected ages, indicating that upper level is contemporaneous with Late Bronze neighboring coastal sta of Chatillon, near Chindrieux, in same $\mathrm{N}$ part of Le Bourget lake, eg, Ly-18: $2730 \pm 160(\mathrm{R}, 1969, \mathrm{v} 11, \mathrm{p} 114)$. Three other results are very close to each other and make lower level contemporaneous with Chalcolithic coastal sta lying in S part of lake at Meymart and dated by Ly-190: $4060 \pm 120(\mathrm{R}, 1975, \mathrm{v} \mathrm{17,} \mathrm{p} \mathrm{57)}$.

\section{La Jonquière series, Foissac, Aveyron}

Samples from several places in La Jonquière grotto, near Foissac, Aveyron $\left(44^{\circ} 30^{\prime} \mathrm{N}, 2^{\circ} 01^{\prime} \mathrm{E}\right)$. Subm 1975 by J Clottes, Dir Antiquités préhist Midi-Pyrénées, Foix (Clottes, 1976).

Ly-1221. La Jonquière, habitation

$\mathbf{3 9 5 0} \pm \mathbf{1 3 0}$

Charcoal from surface sediment near Late Chalcolithic habitation. Coll 1972 by M Lorblanchet and L Genot.

\section{Ly-1592. La Jonquière, Squelette}

$4050 \pm 600$

Bits of charcoal underlying human skeleton without assoc industry but assumed contemporaneous with Chalcolithic habitation. Coll 1975 by $\mathbf{P}$ Soleihavoup; 1/4 diluted sample measured in proportional detector.

Ly-1593. La Jonquière, couches colonnes $\quad 3930 \pm 410$

Charcoal from zone between sepulture and habitation. Coll 1975 by $\mathrm{P}$ Soleihavoup; 2/5 diluted sample.

General Comment $(\mathrm{JC})$ : despite large statistical margins due to scarcity of material, dates are very close. They show that all archaeol remains in grotto are contemporaneous and from same epoch as the one dated Chalcolithic site in Quercy region: Les Grèzes tumulus near Souillac, Lot: Ly-895: $3910 \pm 100(\mathrm{R}, 1976, \mathrm{v}$ 18, p 73).

\section{Le Fournet series, Montmaur, Drôme}

Samples from several levels in Neolithic sepulchral grotto Le Fournet, near Montmaur, Drôme (44 $\left.41^{\prime} \mathrm{N}, 5^{\circ} 20^{\prime} \mathrm{E}\right)$. Coll 1966 by A Héritier and subm by A Cogoluènhes Geol Dept Univ Lyon (Anthony, 1914).

\section{Ly-1733. Le Fournet 4}

$\mathbf{3 9 5 0} \pm \mathbf{1 8 0}$ 1978.

Splinters of human bones from several sqs at base of grotto; subm

\section{Ly-1178. Le Fournet 1}

$4140 \pm 190$

Human tibia from Sq $1 / 2$ at base of grotto. Subm 1975; 2/3 diluted sample.

Ly-1302. Le Fournet 2

$4570 \pm 140$

Charcoal from Sq 10 at middle of grotto. Subm 1975.

Ly-1407. Le Fournet 3

$4720 \pm 200$

Human tibia from Sq 14 in lowest layer at base of grotto. Subm 1976. 4/30 very diluted sample but very long measurement. 
General Comment (AC): series shows sepulchral grotto were used for 2 periods: one period ca 4600 BP may be contemporaneous with Chassean habitation found in grotto nearby, the other period ca 4000 вр during Chalcolithic, assumed from industry assoc with bones. Anthropologic study seems to confirm 2 different populations (Cogoluènhes, 1979).

Ly-1659. Les Sarrasins, 68, Seyssinet-Pariset, Isère $4630 \pm 290$

Charcoal from hearth in Layer 10, Sq B-1, in Les Serrasins grotto, near Seyssinet-Pariset, Isère $\left(45^{\circ} 10^{\prime} \mathrm{N}, 5^{\circ} 41^{\prime} \mathrm{E}\right)$. Coll 1976 and subm 1977 by A Bocquet Dolomieu Inst, Grenoble. Assoc with Late Neolithic ceramic industry. Pollen diagram indicates major deforestation caused by human activity. Comment (AB): confirms Late Neolithic attribution to industry and its contemporaneity with lake margin site of Conjux (above). Three dates from younger layer in site were previously pub ( $R$, 1971, v 13, p 55; R, 1973, v 15, p 52).

\section{Ly-1588. La Roche Dumas, Arsac en Velay, Haute- Loire}

$5120 \pm 320$

Bits of charcoal from Level $3 \mathrm{~b}$ in La Roche Dumas site, near Arsac en Velay, Haute-Loire $\left(44^{\circ} 59^{\prime} \mathrm{N}, 3^{\circ} 56^{\prime} \mathrm{E}\right)$. Coll and subm 1974 by A Crémillieux, Le Monastier sur Gazeille. Assoc crude industry which may be attributed to Chassean culture with respect to another more characteristic industry occurring nearby. $1 / 2$ diluted sample counted in proportional detectors. Comment (AC): sample confirms Middle Neolithic attribution and is similar to Ly-1549, below, from neighboring Le Chambon site (Cremillieux, 1974).

\section{Ly-1549. Le Chambon, Goudet, Haute-Loire}

$5160 \pm 250$

Charcoal from $0.6 \mathrm{~m}$ depth in base of Chassean hut of Le Chambon site, near Goudet, Haute-Loire (44 $\left.50^{\prime} \mathrm{N}, 3^{\circ} 55^{\prime} \mathrm{E}\right)$. Coll and subm 1976 by A Crémillieux. 2/5 diluted sample counted in proportional detectors. Comment (AC): together with Ly-1588, above, dates Chassean of Velay region, despite isolated geog position, from about same epoch as other Chassean industries of France.

\section{Le Camp de César series, La Groutte, Cher}

Samples from 2 levels of Le Camp de César site, near La Groutte, Cher $\left(46^{\circ} 42^{\prime} \mathrm{N}, 2^{\circ} 31^{\prime} \mathrm{E}\right)$. Subm 1977 by J Allain, Dir Antiquités préhist Centre, Bourges. Site is prehistoric camp of barred spur type, isolated from plateau by front rampart, excavation of which proved was continuously occupied from Chassean period (Ly-1515) to Christian era. During beginning of Iron age, rampart was around whole spur as shown by Boring 16 (Ly-1516).

Ly-1516. Camp de César, Sondage 16 $1850 \pm 200$

Charcoal from $1.8 \mathrm{~m}$ depth in burned layer at base of circular Iron age rampart. Coll 1968 by J Allain. 5/6 diluted sample. Comment (JA): date is ca $600 \mathrm{yr}$ too young; sample polluted by roots. 
Ly-1515. Camps de César, fosse

$5000 \pm 170$

Bones from ditch underlying front rampart and belonging to oldest outworks system. Assoc with pure Chassean industry of Bourgogne type. Coll 1974 by M Vannier, Saint-Amand-Montrond. Comment (JA): fits in expected chronologic margins of Les Ponts site (Eure et Loir): Gif: 2774: $4550 \pm 130$, Gif-2772: $4790 \pm 130$ and Gif-2773: $4860 \pm 130$ (Haricot, 1978).

Ly-1350. Buderfeld, Uckange, Moselle $\quad 2100 \pm 150$

Charcoal from $1.2 \mathrm{~m}$ depth in Ditch $\mathrm{C}$ of Danubian Rubané-récent

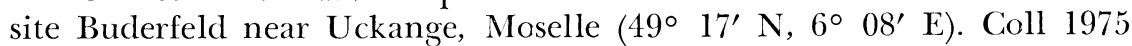
by $V$ Blouet and subm 1976 by $C$ Guillaume. Site is row of ditches with lineal Rubané-Récent industry of rough or decorated potsherds (Lepape, 1970). Comment (CG): by comparison of German sites with similar industry, expected age was ca 4000 BC. Date is much younger and may be explained by fact that sampling was made only some days after opening of ditch, and may have been contaminated.

\section{Bougon series, Deux-Sèvres}

Human bones from lowest archaeol level of funerary room of Neolithic Megalithic necropolis of Bougon (Deux-Sèvres) $\left(46^{\circ} 21^{\prime} \mathrm{N}, 0^{\circ} 11^{\prime}\right.$ W). Coll and subm 1977 by J P Mohen, Mus Antiquités Nath, SaintGermain en Laye. Funerary room is round dolmen with stony corridor buried in cairn and assoc with Tumulus F (Mohen, 1973).

Ly-1699. Bougon, Tumulus FO, Sud

$5480 \pm 170$

Fragment of several bones from S part of room.

Ly-1700. Bougon, Tumulus FO, Nord

$5830 \pm 140$

Femur from $\mathrm{N}$ part of room.

General Comment (JPM): 3 results were previously obtained from site which was occupied for $1500 \mathrm{yr}$, divided in 4 phases (R, 1976, v 18, p 7475): Phase I, the oldest, has not been precisely dated, Phase II occurred in Tumulus $\mathrm{E}(\mathrm{Ly}-966: 5800 \pm 230)$ which fits with Ly-1700 from Tumulus F, while Ly-1699 should mark end of this phase. Phase III corresponds to Chassean industry dated in Tumulus F2 by Ly-967: $4790 \pm 200$ and lately, during Phase IV, monument was reused by Charente-Vienne people also dated in Tumulus F2 by Ly-968: $4470 \pm 230$ (Mohen, 1977).

\section{Schamli series, Reichtett, Bas-Rhin}

Charcoal from 3 ditches of open-air Neolithic site Schamli near Reichtett, Bas-Rhin (48 38 N, 70 45' E). Coll 1976 by J Sainty and subm 1976 by A Thevenin, Dir Antiquités préhist Alsace, Strasbourg.

Ly-1567. Reichtett, Fosse 146

$5930 \pm 250$

From ditch containing industry of Michelsberg style, assumed younger than neighboring Vendenheim site: Ly-866: $4870 \pm 110(\mathrm{R}, 1976$, $\mathrm{v} 18, \mathrm{p} 72)$ assoc with pottery of Lingolsheim group. $1 / 3$ diluted sample. 
Ly-1568. Reichtett, Fosse 107

$6420 \pm 230$

From ditch containing industry of Rubané Récent style, assumed younger than Rubané Ancien level in site. Previously dated using fossil pitch: Ly-865: $5940 \pm 140$ (R, 1976, v 18, p 76). 2/3 diluted sample.

Ly-1569. Reichtett, Fosse 75

$6870 \pm 260$

From ditch with same inclustry as Ly-1568. 1/2 diluted sample.

General Comment (AT): large statistical errors are due to scarcity of carbon available after basic dissolution which solubilized most of sample. Despite this, dates are very consistent with each other but do not fit with expected ages. Discrepancy may be explained by long continuous occupation of site where many ditches were dug in loess to make house walls in wattle (Thevenin et al, 1977), so that ditches might have been used several times and samples and industries of different ages might be mixed.

Ly-1621. Schwindratzeim, Bas-Rhin

$6230 \pm 300$

Charcoal from ditch in open air habitation site at Le Village near Schwindratzeim, Bas-Rhin $\left(48^{\circ} 45^{\prime} \mathrm{N}, 7^{\circ} 36^{\prime} \mathrm{E}\right)$. Coll 1975 by F Wendling and subm 1977 by A Thevenin. Assoc with Rubané Récent industry. Strong dilution in basic treatment involving $1 / 3$ diluted sample. Comment (AT): despite large statistical margin, date should confirm assumed age of Rubané Récent industry. Contrary to Reichtett site, only 1 occupation period occurred in site (Thévenin, 1976).

\section{Mesolithic and Epipaleolithic periods}

\section{Ly-1668. Sous Balme, Culoz, Ain}

$\mathbf{8 6 4 0} \pm 380$

Human bones assoc with Sauveterrian industry, from sepulture dug in thick ashy layer containing same industry in W part, called "Abri", of Sous Balme site, at Culoz, Ain ( $\left.45^{\circ} 5^{\prime} \mathrm{N}, 5^{\circ} 47^{\prime} \mathrm{E}\right)$. Coll 1959 and subm 1977 by R Vilain, Dept Geol, Univ Lyon; 2/5 diluted sample Comment $(\mathrm{RV})$ : in statistical range of Ly-286: $9150 \pm 160(\mathrm{R}, 1973, \mathrm{v} 15, \mathrm{p} 142)$ from charcoal of ashy layer. Date proves that sepulture marks end of rockshelter occupation.

\section{La Borie del Rey series, Blanquefort, Lot et Garonne}

Bones from 2 levels in La Borie del Rey grotto, near Blanquefort, Lot et Garonne (44 $36^{\prime}$ N, $0^{\circ} 58^{\prime} \mathrm{E}$ ). Coll 1973, subm 1977 by J M Le Tensorer, Inst Géodynamique, Univ Bordeaux. Site was formerly excavated by L Coulonges (1963).

\section{Ly-1402. La Borie del Rey, Couche 3}

$9870 \pm 320$

From Layer 3 (= Coulonges' Layer 4) assoc with Epi-Azilian industry with microliths, called "Epilaborian". Sedimentologic analyses indicate cool followed by temperate climate; $2 / 3$ diluted sample.

Ly-1401. La Borie del Rey, Couche 5

$10,350 \pm 340$

From Layer 5 (= Coulonges' Layer 3) assoc with peculiar Azilian industry, called "Laborian". Sedimentologic analyses indicate cold and 
fairly humid climate suggesting middle of Late Dryas period; 2/3 diluted sample.

General Comment (JM LT): both dates are consistent with each other. They fit in range of dates expected by Late Dryas attribution of levels given by sediment studies and absence of reindeer in assoc fauna (Le Tensorer, 1979).

\section{Chez-Jugie series, Cosnac, Corrèze}

Charcoal from several levels and loci in Chez-Jugie rockshelter near Cosnac Corrèze $\left(45^{\circ} 07^{\prime} \mathrm{N}, 1^{\circ} 36^{\prime} \mathrm{E}\right)$. Coll and subm by G Mazière, Dir Antiquités Préhist Limousin, Limoges and JP Raynal, Inst Quaternaire, Univ Bordeaux. Rockshelter is in sandstone cliff. Erosion has caused loose sand in which small bits of charcoal are scattered. As $\mathrm{pH}$ of sediment varies between 4 and 6 , bone remains were too small to be used for dating. Charcoal samples were used despite scarcity of material after treatment and risks of contamination by roots, rootlets, and burrows. Assoc industry suggests 2 occupation periods: Sauveterrian in Layer 3 and Azilian in Layer 5 (Mazière, 1978; Mazière \& Raynal, 1978).

\section{Ly-1330. Chez-Jugie, I}

$1890 \pm 200$

From base of Layer 2, Sq J-III, underlying microlithic industry with Le Martinet trapezoǐds. Coll 1975 and subm 1976. Assumed contamination. $1 / 5$ diluted sample.

\section{Ly-1395. Chez-Jugie, V}

$4540 \pm 200$

From top of Layer 3, Sq I-IV. Coll 1974 and subm 1977. Assoc with industry, probably redeposited, with Le Martinet trapezoǐds. 1/2 diluted sample.

Ly-1600. Chez-Jugie, IV

$7010 \pm 430$

From upper part of Layer 3, Sq H-III, assoc Sauveterrian industry. Coll 1974 and subm 1977. 1/3 diluted sample counted in proportional detectors.

Ly-1396. Chez-Jugie, III

$7060 \pm 140$

From upper part of Layer 3, Sq H-III. Coll 1975 and subm 1977. Assoc with Sauveterrian industry with trapezolds.

\section{Ly-1652. Chez-Jugie, XV}

$8080 \pm 280$

From middle of Layer 3, Sq H-III and H-IV. Coll 1977 and subm 1978. Assoc with Sauveterrian industry with micro-triangles. 23/30 diluted sample.

\section{Ly-1331. Chez-Jugie, II}

$\mathbf{8 0 4 0} \pm 260$

From middle of Layer 3, Sq H-III. Coll 1975 and subm 1976. Assoc with Sauveterrian industry with micro-triangles. 2/3 diluted sample. 
Ly-1651. Chez-Jugie, XIV

$\mathbf{7 6 5 0} \pm \mathbf{5 1 0}$

From base of Layer 3, Sq I-IV. Coll 1977 and subm 1978. Assoc with Sauveterrian industry with micro-triangles. $1 / 2$ diluted sample counted in proportional detectors.

Ly-1572. Chez-Jugie, XII

$\mathbf{1 1 , 8 4 0} \pm \mathbf{5 8 0}$

From whole Layer 5, Sq A-III. Coll 1976 and subm 1977. Assoc with Azilian industry. $1 / 3$ diluted sample.

\section{Ly-1601. Chez-Jugie, I \& XIII}

$11,730 \pm 530$

From base of Layer 5, Sq A-II. Coll 1976 and subm 1977 and 1978. Assoc with Azilian industry. $1 / 2$ diluted sample counted in proportional detectors.

\section{Ly-1802. Chez-Jugie, XVI \& XVII}

From extreme base of Layer 5, Sq J-II and H-III. Coll and subm 1978. Assoc with scarce pré-Azilian industry.

General Comment (GM and JPR): despite difficulties of measurements and risk of contamination, most results are consistent. Ly-1330 and -1395 may show evidence of human caused stratigraphic disturbance and contamination by recent roots. A Mesolithic occupation of site with Le Martinet trapezořds took place about 7000 вP (Ly-1600 and -1396). Two dates from middle part of Layer 3, Ly-1331 and -1652, attribute satisfactory age, ca 8000 вP, to typical Sauveterrian industry. Ly-1651, a little younger, may correspond to end of Sauveterrian period as excavation revealed basin hearths dug into underlying layers by last Sauveterrian people. Statistical fluctuation or slight contamination may have occurred. Layer 5, with Azilian industry, seems to be from beginning of Alleröd period, according to Ly-1572 and -1601. Statistical margin of Ly-1802 make this result less significant but it does not disagree with other results. Entire series agrees with conclusions deduced from sedimentologic, botanic, and paleontologic studies which attribute Azilian industry to Alleröd climatic phase and Sauveterrian to boundary of Boreal and Atlantic periods (Mazière \& Raynal, 1977).

\section{Zatoya series, Abaurrea Alta, Navarra, Spain}

Samples from several levels in Zatoya grotto, near Abaurrea Alta, Navarra, Spain $\left(42^{\circ} 54^{\prime} \mathrm{N}, 1^{\circ} 15^{\prime} \mathrm{W}\right)$. Coll 1976 and subm 1977 by I Barandiaran, Univ Santander. Site has presumably continuous stratigraphy from end of Late Paleolithic to Neolithic periods.

\section{Ly-1397. Zatoya, ZM 31}

$6320 \pm 280$

Bones from Level I, Sq 5-Z, 80 to $85 \mathrm{~cm}$ depth. Assoc with Early and Middle Neolithic industry and presumably of Atlantic period. 1/2 diluted sample.

Ly-1457. Zatoya, ZM 33

$8260 \pm 550$

Charcoal from Level I, Sq 1Z, 120 to $125 \mathrm{~cm}$ depth. Assoc with Epipaleolithic industry with geometric microliths. Presumably of beginning Atlantic period. 7/30 very diluted sample. 
$\begin{array}{ll}\text { Ly-1398. Zatoya, ZM 25 } & 8150 \pm 170\end{array}$

Charcoal from upper part of Level II, Sq 3A, at $140 \mathrm{~cm}$ depth. Assoc with Epipaleolithic industry without geometrics. Presumably of Boreal period.

Ly-1599. Zatoya, ZM 27

$11,620 \pm 360$

Small amount of bones from Level II, Sq 3B, 150 to $160 \mathrm{~cm}$ depth. Assoc with industry of Azilian type with micro-grattoirs. Probably from Boreal or Pre-Boreal periods. 1/3 diluted sample counted for a long time in proportional detector.

Ly-1399. Zatoya, ZM 47

$11,480 \pm 270$

Bones from lower part of Level II, Sq 1Z, 170 to $180 \mathrm{~cm}$ depth. Assoc with industry of Azilian type in Late Paleolithic tradition. Probably of Pre-Boreal period.

Ly-1458. Zatoya, ZM 29

$\geqslant 10,940$

Bones from Level b $\mathrm{b}^{3}$, Sq 15B, 212 to $227 \mathrm{~cm}$ depth. Assoc with Azilian industry with micro-grattoirs. Presumably of Boreal or Pre-Boreal periods. Min age given, as only 1 count could be made because of laboratory accident. $1 / 3$ diluted sample.

Ly-1400. Zatoya, ZM 34 $\quad 11,840 \pm 240$ $231 \mathrm{~cm}$.

Bones from same level assoc with same industry in Sq 13B, 209 to

General Comment (IB): despite difficulties of measurements for some samples due to scarcity of material, series is coherent and may be divided in 2 parts: 3 1st results conform with expected ages and show that passage from Mesolithic to Neolithic took place at beginning of Atlantic period (Barandiaran, 1977). Four other results are older than expected, as they indicate Alleröd period instead of Pre-Boreal. This should mark long hiatus in sedimentation at Level II and, thus, Azilian industry should be contemporaneous with many other Epipaleolithic industries in S France.

\section{Mallaha series, Eynan, Israel}

Small amounts of charcoal from 2 soils in open air site Mallaha, near Houlé lake, Eynan dist, Israel $\left(33^{\circ} 05^{\prime} \mathrm{N}, 35^{\circ} 35^{\prime} \mathrm{E}\right)$. Subm 1977 by $\mathrm{F}$ Valla, French Mission Centre Natl recherches sci, Jerusalem, Israel. Mallaha may be oldest sedentary habitation site presently known. Site consists of bases of circular huts, 5 to $10 \mathrm{~m}$ diam, in which was found Late Paleolithic, Natufian, industry of Levant region. This industry occurs between Kebarian and prepottery Neolithic A types. Expected ages lies between 11,000 and 12,000 BP; (Lechevallier \& Valla, 1974).

Ly-1662. Mallaha, 4012

$11,310 \pm 880$

From soil of House 51. Coll 1975 by M Lechevallier. Marks old occupation phase of site. $1 / 6$ very diluted sample. 
Ly-1661. Mallaha, 4040

$11,740 \pm 570$

Same origin as previous one. 8/30 diluted sample.

Ly-1660. Mallaha, 4568

$11,590 \pm \mathbf{5 4 0}$

From soil of House 131. Coll 1976 by F Valla. Marks oldest occupation phase of site. $1 / 2$ diluted sample counted in proportional detectors. General Comment (FV): despite large statistical margins, dates are in expected time period. Industries assoc in both soils are from same Early Natufian phase but, as Soil 131 underlies Soil 51, statistical fluctuations apparently inverted 2 soil dates that are very close to each other.

\section{Late and Middle Paleolithic periods}

\section{Les Romains series, Virigin, Ain}

Small bits of charcoal from 3 Magdalenian levels in Les Romains grotto at Pierre-Châtel, near Virignin, Ain $\left(45^{\circ} 41^{\prime} \mathrm{N}, 5^{\circ} 21^{\prime} \mathrm{E}\right)$. Coll 1969 and subm 1976 by R Desbrosse, Blanzy (Desbrosse, 1976).

\section{Ly-1594. Les Romains, Niveau IIa $\quad 10,100 \pm 350$}

From Level IIa, $1 / 2$ diluted sample counted for a long time in proportional detectors.

\section{Ly-1307. Les Romains, Niveau IIb}

$10,280 \pm 630$

From Level IIb, $7 / 30$ very diluted sample.

\section{Ly-1308. Les Romains, Niveau III}

$10,770 \pm 410$

From Level III, $1 / 2$ diluted sample.

General Comment (RD): series seems too young for assoc Late Magdalenian industry. Previous measurements were made on bones: Ly-356: $12,980 \pm 240(\mathrm{R}, 1973, \mathrm{v} 15, \mathrm{p} 167)$ from Level III; on charcoal: Ly-16: $14,380 \pm 380(\mathrm{R}, 1969, \mathrm{v} 11, \mathrm{p} 116)$ from Level IIa; on gastropod shells: MC-1274: $8230 \pm 110$ and MC-1275: 12,540 \pm 400 from Level IIb and MC-1276: $12,540 \pm 230$ from Level III (unpub). Discrepancy of dates may be due to downward migration of charcoal or rootlets or to environment and biological effect of terrestrial shells (Evin \& Maréchal, 1979).

\section{Ly-1729. Longetraye 6D C1, Freycenet la Cuche, Haute Loire}

$9360 \pm 270$

Charcoal from Layer 1 in $\mathrm{Sq} 6 \mathrm{D}$ of basaltic rockshelter Longetraye,

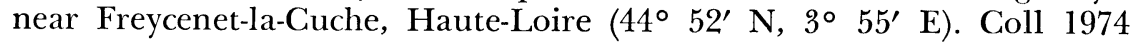
and subm 1977 by D Philibert, Univ Lyon. Assoc with Late Magdalenian industry. Comment (DP): does not agree with Ly-512: 12,720 \pm 750, from Layer 4, Sq 6E in site, assoc with same industry ( $R, 1973, v 15, p 524)$ (Elouard et al, 1974). Date is too young either because of downward migration of charcoal, frequently occurring in fillings of such basaltic site, or because Layer 1 is transition level between Magdalenian occupation (Ly-512) and subsequent Mesolithic settlement from which several samples were dated: Ly-760: $8590 \pm 590(\mathrm{R}, 1975, \mathrm{v} 17, \mathrm{p} 22)$. 


\section{Ly-1351. Les Coudrays, Etiolles, Essonne}

Fragment of Elephas primigenius scapula from 4th occupation level from surface in open-air site Les Coudrays, near Etiolles, Essonne. Coll and subm 1975 by Y Taborin, Univ Paris I. Assoc with Late Magdalenian industry. Climatic phase presumably cold because of frost-fractured flints (Taborin, 1977). Comment (YT): in expected range of dates according to Hamburgian character of industry in region.

\section{Ly-1406. Espelugues, Lourdes, Hautes Pyrénées $\quad 13,170 \pm 260$}

Bones from base of S gallery, Loc 1, Espelugues grotto, at Lourdes, Hautes Pyrénées $\left(43^{\circ} 06^{\prime} \mathrm{N}, 0^{\circ} 03^{\prime} \mathrm{W}\right)$. Coll and subm 1976 by J Omnès, Lourdes. Assoc with some artifacts of Late Magdalenian industry (Omnès, 1977). Comment (JO): agrees with attribution of industry to Late phase of Magdalenian. May be compared to Espèche series, below, and to Layer IV in Duruthy site (Magdalenian IV): Ly-859: 13,510 \pm 220 , and $L y-860: 13,840 \pm 210$ (R, 1976, v 18, p 79).

\section{Le Bois du Cantet series, Espèche, Hautes Pyrénées}

Bones from 2 levels of Le Bois du Cantet grotto at Espèche, Hautes Pyrénées $\left(43^{\circ} 03^{\prime} \mathrm{N}, 0^{\circ} 08^{\prime} \mathrm{E}\right)$. Coll 1964 and 1972 and subm 1976 by A Clot, Bordères-sur-Echez.

Ly-1403. Le Bois du Cantet, Sec II

$13,370 \pm 270$

Bones coll on stalagmitic floor in Sec II of grotto, assoc with Magdalenian industry.

\section{Ly-1404. Le Bois du Cantet, Sec I}

$13,060 \pm 430$

Bones coll in archaeol layer under stalagmitic floor in Sec I of grotto. Assoc with Late Magdalenian industry. 2/3 diluted sample.

General Comment (AC): both dates agree statistically and should indicate homogeneous occupation of site. Date is compatible with archaeol attribution of industry to Late Magdalenian (Clot \& Cantet, 1974). Comparable to Ly-1406, above, and slightly younger than Ly-1405, below, and Caubeta series (R, 1978, v 20, p 48): Ly-1107: 13,910 \pm 230 and Ly-1055: $14,280 \pm 300$ with similar assoc industry (Clot \& Omnès, 1979).

\section{Ly-1405. La Grande Grotte, Labastide, Hautes Pyrénées}

$14,260 \pm 440$

Bones found on surface grotto filling $400 \mathrm{~m}$ inside La Grande Grotte, near Labastide, Hautes Pyrénées $\left(43^{\circ} 08^{\prime} \mathrm{N}, 0^{\circ} 23^{\prime} \mathrm{E}\right)$. Coll and subm 1976 by J Omnès. Formerly excavated grotto on sampling site contained hearths with engraved plates of stone and Magdalenian IV industry (Begouën, 1938). 5/6 diluted sample. Comment (JO): agrees with archaeol attribution and with Caubeta series (R, 1978, v 20, p 48, and above) (Clot \& Omnès, 1979).

\section{Ly-1628. Paglicei IV-73, Rignano Garganico, Foggia, Italy}

Bones from Level 7c, Sq 35NOP in Paglicci grotto, near Rignano

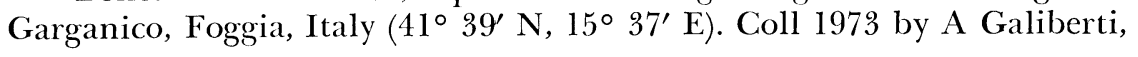


and subm 1976 by P Gambassini, Inst Antropol Paleontol Umana, Univ Siena. Assoc with Epigravettian industry. Expected age: ca 14,000 BP. $1 / 6$ very diluted sample. Comment $(\mathrm{PG})$ : close to expected age, but ca 1000 yr younger than charcoal sample from same Level: F-65: 14,800 \pm 210 (R, 1977, v 19, p 165). Large statistical margin due to small amount of organic matter preserved in bones may explain difference in apparent age.

\section{Lascaux series, Montignac, Dordogne}

Bits of charcoal from 2 locations in gallery called "Diverticule axial"

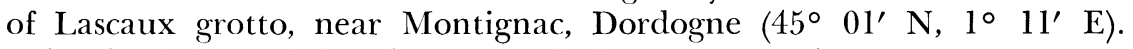
Subm by Arl Leroi-Gourhan, Mus de l'Homme, Paris.

\section{Ly-1196. Cheval renversé de Lascaux $7510 \pm 650$}

From upper clay filling of gallery, under painting called "Cheval renversé”. Coll 1959 by A Glory and subm 1975. 1/5 diluted sample.

\section{Ly-1197. Faille Méandre de Lascaux $\quad \mathbf{8 6 6 0} \pm 360$}

From clayey filling in small fissure in wall at meander of gallery. Coll 1975 by Arl Leroi-Gourhan. 1/2 diluted sample.

General Comment (AL): samples were subm once more to date painting and Early Magdalenian industry with which all clayey filling was assumed contemporaneous. Three results were previously pub for unique human occupation of Lascaux grotto ca 16,800 BP at end of Lascaux interstade (Libby, 1955, p 85; R, 1963, v 5, p 168; R, 1964, v 6, p 247). Present results and new studies (Leroi-Gourhan \& Allain, 1979) show that clayey sediments in "diverticule" gallery are probably redeposited. Holocene charcoal has already been found and dated at entrance of grotto: GrN-1182: $8510 \pm 100$ and in "Les Gours" passage: GrN-1514: $8300 \pm 75$ and GrN-1182: $9070 \pm 90$ (De Vries \& Waterbolk, 1958). Thus presence of Holocene charcoal in axial gallery demonstrates transport of sediments by water in grotto during Boreal period (Leroi-Gourhan \& Evin, 1979).

\section{Terre Sève series, Solutré, Saône et Loire}

Bones from several levels in Terre Sève zone of Solutré foot of limestone cliff site, Saône et Loire $\left(46^{\circ} 18^{\prime} \mathrm{N}, 4^{\circ} 43^{\prime} \mathrm{E}\right)$. Coll and subm 1976 by J Combier, Dir Antiquités Préhist, Rhône-Alpes, Romanèche-Thorins.

Ly-1530. Terre Sève de Solutré, 165-170

$13,680 \pm 240$ industry.

From Sqs I/10-37, 165 to $170 \mathrm{~cm}$ depth. Assoc with Magdalenian

\section{Ly-1531. Terre Sève de Solutré, 170-175}

$13,710 \pm 230$ industry.

From Sqs I/10-37, 170 to $175 \mathrm{~cm}$ depth. Assoc with Magdalenian

\section{Ly-1532. Terre Sève de Solutré, 180-190}

$14,360 \pm 280$

From Sqs I/10-37-47-57, 180 to $190 \mathrm{~cm}$ depth. Assoc with Middle Magdalenian industry containing same bone points with geometric decora- 
tion found in Arlay site, below. Sediments lying from 175 to $180 \mathrm{~cm}$ depth are sterile and there is no Magdalenian industry lower than $190 \mathrm{~cm}$ level.

Ly-1533. Terre Sève de Solutré, Strate supérieure

$19,590 \pm 280$

From Sqs I/11-97 and I/10-7, 240 to $250 \mathrm{~cm}$ depth. Assoc with a Middle Solutrean industry.

\section{Ly-1534. Terre Sève de Solutré, Strate} inférieure

From Sqs I/10-37-47-57, 210 to $250 \mathrm{~cm}$ depth. Assoc with Middle Solutrean industry.

General Comment (JC): Except for Ly-1534, all dates are consistent with each other and with expected values. Ly-1530 and -1531 places Magdalenian industry before Late Magdalenian level previously dated from another sec of site: Ly-393: 12,580 \pm 250 (R, 1973, v 15, p 148) and after Ly-1532, which is comparable to 4 results from Magdalenian levels of Arlay site, below. Ly-1533 perfectly agrees with GrN-4442: 19,600 \pm 140 and GrN-4495: 19,740 $\pm 140(\mathrm{R}, 1967, \mathrm{v} 9, \mathrm{p}$ 116) from Level 5 of Laugerie Haute site, Dordogne, which contains same Middle Solutrean industry. Ly-1534, from lowest level of Middle Solutrean level, might be older than Ly-1533; it is however, similar to previous result from level with same industry: Ly-316: 17,150 $\pm 300(\mathrm{R}, 1974, \mathrm{v} 14, \mathrm{p}$ 63). This remains unexplained and may be coincidental.

\section{Grotte Grapin series, Arlay, Jura}

Bones and reindeer horns from Level C of Grapin grotto, near Arlay, Jura $\left(46^{\circ} 46^{\prime} \mathrm{N}, 5^{\circ} 3 \mathrm{I}^{\prime} \mathrm{E}\right)$. Coll 1961 by M Vuillemey, Lons le Saunier, and subm 1976 by J Combier. Level corresponds to cold climate with steppic fauna. Assoc peculiar type of Magdalenian industry is not easily correlated with classic Magdalenian of SW France.

\section{Ly-1509. Arlay Niveau C, Bois de Renne, partiel}

Small amount of reindeer horn, $1 / 3$ diluted sample.

\section{Ly-1535. Arlay Niveau C, Bois de Renne}

Reindeer horn.

\section{Ly-1510. Arlay Niveau C, Os de Renne}

Reindeer bones.

\section{Ly-1536. Arlay Niveau $C$, Os et bois de Renne}

Mixing of fragments of bones and horns of reindeer.

$14,220 \pm 560$

$14,530 \pm 290$

$14,820 \pm 370$

$14,840 \pm 360$

General Comment (JC): 2 previous results from same site, Ly-457: 15,320 \pm 370 and Ly-559: $15,770 \pm 390(\mathrm{R}, 1973$, v 15, p 520) were too old for assoc industry. Sampling of those former measurements is now questionable: it may have been mixing of Magdalenian bones with some bone fragments of carnivore sp from lowest level of site dated twice from ca 
25,500 вр (Ly-498 and -499). Both present results remain a little older than expected and than Level D of La Colombière site: Ly-433: 13,390 $\pm 300(\mathrm{R}, 1973, \mathrm{v} 15, \mathrm{p} 149)$ but they agree with Ly-1532 from Solutré site, above. The 2 samples (bones and horns) were carefully selected from zone of site where sterile level separates Magdalenian and older nonartifact bearing levels; chosen bone-splinters also had butchery marks (Combier \& Vuillemey, 1976).

\section{Laraux series, Lussac les Châteaux, Vienne}

Bones from 2 levels in Laraux Rockshelter, near Lussac les Châteaux, Vienne (46 24' N, 0 43' E). Coll 1949 and subm 1978 by L. Pradel Chatellerault. Sterile level separates overlying Layer 3 from Layer 5 (Pradel \& Cholet, 1950).

\section{Ly-1739. Laraux, Couche $3 \quad 21,530 \pm 910$}

From Layer 3, assoc with Perigordian $\mathrm{V}_{\mathrm{c}}$ industry with Noailles and Le Raysse burins. 1/3 diluted sample.

Ly-1740. Laraux, Couche 5

$23,510 \pm 640$

From Layer 5, assoc with Perigordian $V_{b}$ industry with truncated artifacts of same type as those from Layer $\mathrm{K}$ in La Ferrassie site, Dordogne, where there is also a Late Perigordian industry.

General Comment (LP): age difference between both levels is greater than expected but may be explained by large statistical margin of Ly1739, which seems a little too young by comparison with dates of Late Perigordian industries in W France, eg, Abri Pataud (R, 1969, v 9, p 113). Date is contemporaneous with Proto-Magdalenian levels of Abri Pataud and Laugerie Haute sites (R, 1963, v 5, p 167). Ly-1740 perfectly agrees with Late Perigordian dates from these 2 sites and fits with 6 other Gif lab results from 22,500 to 24,600 вP from Late Perigordian levels of La Ferrassie site (Delibrias et al, 1976, p 1509). Absolute chronology of beginning of Late Paleolithic is not well known even in W part of France and comparisons with similar industries in other regions are questionable. Two similar dates exist, however, from $\mathrm{E}$ France sites containing Late Perigordian industries: Ly-309: 24,150 \pm 550 from Saint-MartinSous-Montaigu, and Ly-317: 24,050 \pm 600 from Solutré (R, 1969, v 13, p 63).

\section{La Baume de Gigny series, Gigny sur Suran, Jura}

Bones from 2 upper levels of filling of La Baume site near Gigny sur Suran, Jura $\left(46^{\circ} 27^{\prime} \mathrm{N}, 5^{\circ} 27^{\prime} \mathrm{E}\right)$. Coll and subm 1978 by M Vuillemey. Site consists of thick filling in narrow fissure of limestone cliff (Piningre \& Vuillemey, 1976).

Ly-1798. La Baume de Gigny, Niveau IV, No. $2 \quad 12,370 \pm 460$

Bones of small mammals from Upper and Middle part of Level IV from side of walls of rock fissure. Coll 1978, assoc with undiagnostic industry; $1 / 2$ diluted sample. Comment (MV): dated to check following 
measurement to detect contamination by migration of small bones. Bones were carefully selected and sampled from layer out of contact with underlying Level V.

Ly-1702. La Baume de Gigny, Niveau IV, No. $1 \quad 13,620 \pm 480$

Bones of small mammals from entire Level IV in middle of rock fissure. Coll 1972 and 1973. Fauna is mixture of very cold and forest sp; $2 / 5$ diluted sample.

Ly-1703. La Baume de Gigny, Niveau V

$22,430 \pm 500$ industry.

Bear and microfauna bones from Level V. Assoc with undiagnostic

General Comment (MV): both results from Level IV are very close to each other and in stratigraphic order. They are older than expected by malaco-fauna which suggest Atlantic period. Instead of Pre-Boreal or Boreal periods which might be assumed by the mixing of mammifera sp, Ly-1798 and -1702 attribute Level IV to Late Würm (Würm IV) and the rather temperate climatic phase could be Bölling. Ly-1703 occurs in expected range of date and confirms that upper part of fissure filling belongs to Late Würm III. Older levels of site (Levels VIII, XV, and XX) corresponding to Early Würm (Würm III or II) were previously dated (R, 1973, v 15, p 521; R, 1976, v 18, p 83).

Ly-1579. Le Trou du Renard, Soyons, Ardèche

Bones from 1.5m depth in Boring 2 of Le Trou du Renard site, near Soyons, Ardèche $\left(44^{\circ} 54^{\prime} \mathrm{N}, 4^{\circ} 50^{\prime} \mathrm{E}\right)$. Coll and subm 1976 by V Dumazel and A Grève, Soyons. Assoc with Mousterian industry presumed from beginning of Würm III. Comment (VD): agrees with expected age as chronology and definition of Würm II/III interstadial is still uncertain. As bedrock lies $1 \mathrm{~m}$ below sampling level, unlimited ${ }^{14} \mathrm{C}$ result leads to possibility of obtaining older ages by other dating methods.

\section{HYDROGEOLOGIC SAMPLES}

\section{E Lyon aquifer system series, France}

Samples from wells in E Lyon region, coll by J Evin and G Marien to monitor ${ }^{14} \mathrm{C}$ activities of ground waters previously sampled from Spring 1971 to Autumn 1973. Previous results and description of aquifer were pub in Lyon V (R, 1975, v 17, p 29). All present samples were coll Autumn 1977 in "Couloir de Décines" geol unit from sites selected by D Rousselot, Bur recherches Geol Min, Lyon, except Ly-1158 which comes from "Couloir d'Heyrieux" and was suggested by N Mongereau, Dept Geol, Univ Lyon and coll Autumn 1976.

General Comment: all values are same as those obtained 5 yr earlier. They confirm that no change occurred in aquifer system despite extension of industrial zone in E Lyon region and operation of new airport of Satolas. As before, 2 superimposed free ground waters of the aquifer are distinguishable. Values about $70 \%$ modern indicate waters from lowest level of aquifer from which Satolas airport is supplied (Ly-1634). 
Values about $85 \%$ modern indicate upper level of aquifer, while ${ }^{14} \mathrm{C}$ activities higher than $100 \%$ modern come from surface rain waters (Evin et al, 1979).

\begin{tabular}{|c|c|c|c|c|c|}
\hline Sample no. & Sample & N Lat & E Long & $\begin{array}{l}\text { Dilu- } \\
\text { tion } \\
\text { ratio }\end{array}$ & $\begin{array}{c}{ }^{14} \mathrm{C} \% \\
\text { Modern }\end{array}$ \\
\hline Ly-1636. I & Puits Troquet, No. 1 & $45^{\circ} 45^{\prime}$ & $5^{\circ} 4^{\prime}$ & $1 / 2$ & $115.8 \pm 3.2$ \\
\hline Ly-1637. S & Saugnieu, No. 1 & $45^{\circ} 43^{\prime}$ & $5^{\circ} 6^{\prime}$ & $2 / 3$ & $109.5 \pm 3.1$ \\
\hline Ly-1550. 1 & Ferme de Montchat, No. 1 & $45^{\circ} 41^{\prime}$ & $5^{\circ} 5^{\prime}$ & $\mathrm{l} / 2$ & $88.7 \pm 2.8$ \\
\hline Ly-1638. I & Meyzieux ville, No. 1 & $45^{\circ} 47^{\prime}$ & $5^{\circ} 0^{\prime}$ & $2 / 3$ & $88.1 \pm 2.6$ \\
\hline Ly-1639. I & Meyzieux zone industrielle, No. 4 & $45^{\circ} 46^{\prime}$ & $5^{\circ} 1^{\prime}$ & $2 / 3$ & $83.8 \pm 2.6$ \\
\hline Ly-1634. I & Ferme de Planaise, No. 1 & $45^{\circ} 43^{\prime}$ & $5^{\circ} 4^{\prime}$ & $2 / 5$ & $84.5 \pm 2.8$ \\
\hline Ly-1633. S & Satolas Aéroport, No. 3 & $45^{\circ} 44^{\prime}$ & $5^{\circ} 2^{\prime}$ & $1 / 2$ & $71.8 \pm 2.5$ \\
\hline Ly-1635. S & Satolas Carrière Perrier, No. 2 & $45^{\circ} 42^{\prime}$ & $5^{\circ} 4^{\prime}$ & $5 / 6$ & $74.9 \pm 2.2$ \\
\hline Ly-1158. S & Saint-Pierre de Chandieu, No. 1 & $45^{\circ} 39^{\prime}$ & $5^{\circ} 1^{\prime}$ & $1 / 3$ & $73.6 \pm 2.9$ \\
\hline
\end{tabular}

\section{Az Zawiah series, NW Lybia}

Samples from aquifer system around Az Zawiah, NW region of Lybia (32 $52^{\prime} \mathrm{N}, 12^{\circ} 56^{\prime} \mathrm{E}$ ). Coll 1974 by GERSAR Soc during program of studies called GEFLI and subm 1974 by A Marcé, Bur recherches Geol Min, Orléans. As Miocene limestone of Cyrenaic in NE Lybia (Castany et al, 1974), aquifer is confined with natural outlets along Mediterranean sea coast.

\begin{tabular}{|c|c|c|c|c|c|}
\hline $\begin{array}{c}\text { Sample } \\
\text { no. }\end{array}$ & Sample & \multicolumn{2}{|c|}{ Localization } & $\begin{array}{l}\text { Dilution } \\
\text { ratio }\end{array}$ & $\begin{array}{c}{ }^{14} \mathrm{C} \% \\
\text { Modern }\end{array}$ \\
\hline Ly-930. & Wadi Al Hira & RDHl & $18 / 11 / 73$ & 1 & $4.5 \pm 0.4$ \\
\hline Ly-931. & Wadi R'Mel & DW2 & $14 / 02 / 74$ & $2 / 3$ & $3.4 \pm 0.5$ \\
\hline Ly-932. & Az Zawiah & GZW & $15 / 02 / 74$ & $1 / 3$ & $7.8 \pm 1.2$ \\
\hline Ly-933. & Az Zawiah & GZW4 & $26 / 11 / 73$ & $1 / 2$ & $7.8 \pm 0.7$ \\
\hline Ly-934. & Az Zawiah & GZW3 & $7 / 01 / 74$ & $2 / 3$ & $4.7 \pm 0.5$ \\
\hline Ly-935. & Az Zawiah & GZW6 & - & $2 / 3$ & $2.2 \pm 0.4$ \\
\hline Ly-936. & Az Zawiah & GZW5 & - & $1 / 2$ & $6.0 \pm 0.7$ \\
\hline Ly-947. & Az Zawiah & DWI & longue durée & $1 / 2$ & $10.8 \pm 0.6$ \\
\hline Ly-948. & Wadi R'Mel & DW2 & $13 / 03 / 74$ & 1 & $4.7 \pm 0.4$ \\
\hline Ly-949. & Wadi R'Mel & DW5 & $30 / 03 / 74$ & 1 & $5.2 \pm 0.3$ \\
\hline $\mathbf{L y}-950$. & Wadi R'Mel & DW6 & $13 / 04 / 74$ & $1 / 2$ & $3.1 \pm 0.5$ \\
\hline Ly-951. & Wadi Al Hira & RDM3 & $23 / 05 / 74$ & 1 & $2.6 \pm 0.3$ \\
\hline Ly-992. & Tawarghah & Source & $8 / 07 / 74$ & $2 / 3$ & $2.3 \pm 0.7$ \\
\hline Ly-993. & Tawarghah & $\mathrm{T} 4$ & $7 / 07 / 74$ & $1 / 3$ & $3.4 \pm 0.7$ \\
\hline Ly-994. & Tawarghah & TW1 & $9 / 07 / 74$ & $2 / 3$ & $1.6 \pm 0.3$ \\
\hline
\end{tabular}

General Comment: contrary to Cyrenaic series ( $\mathrm{R}, 1976, \mathrm{v} 18, \mathrm{p} 85)$ and despite expected values, results show very low ${ }^{14} \mathrm{C}$ content in entire aquifer, indicating lack of recent feeding in region.

\section{REFERENCES}

Ambert, P, Evin, J, and Gabert, P, 1974, Datation d'un horizon lithochrome würmien en Basse Provence Occidentale: Acad sci (Paris) Comptes rendus, ser D, v 278, p 33-35.

Anthony, 1914, Les ossements humains vraissemblablement quaternaires recueillis par le Dr Laval dans la grotte du Fournet: Rev Anthropologique, v 1914, no. 3, p 107-116.

Arnaud, G, Arnaud, S, Ascenzi, A, Bonucci, E, and Graziani, G, 1978, The problem of preservation of human bones in sea water: Jour Human Evolution, $v$, no. 6 , p 409-420. 
Azzi, C M, Biglioca, L, and Gulisana, F, 1977, Florence radiocarbon dates II: Radiocarbon, v 19, p 165-169.

Barandiaran, I, 1977, El proceso de transition Epipaleolitico-Ncolitico en la cueva de Zatoya: Rev Principe Viana, v 146-147, p 5-46.

Bazile, F, 1974, Nouvelles données sur l'age des cordons littoraux récents du golfe d'Aigues-Mortes: Actes Colloquium "Approche géologique des quinzes derniers millénaires”: Soc Languedocienne Geogr Bull, v 8, p 199-206. 1976, Les lignes de rivage quaternaire du Languedoc méditerranéen: La Préhistoire Française: Paris, CNRS Press, v 1, p 326-329.

de Beaulieu, J L, 1977, Contribution pollenanalytique à l'histoire tardiglaciaire et holocène de la végétation des Alpes méridionales françaises: Thesis, Univ Marseille, $358 \mathrm{p}$.

Begouën, H, 1938, Les Plaquettes de pierre gravćes de la grotte de Labastide (Hautes Pyrénées): Ipek, Berlin, v X, p 1-10.

Berthier, S, 1978, Une maison du quartier de la mosquée à Koumbi Saleh: Mém Maîtrise d'Histoire, Univ Lyon II, preprint.

Bezinge, A, 1974, Vieux troncs morainiques et climats postglaciaires sur les Alpes: Coll Soc Hydrotechnique Grenoble Comptes rendus, 7-8 March 1974, 34 p.

Bonnamour, L, 1974, Trouvailles de la fin de l'Age du Bronze dans la Saône, sur le site d'Ouroux-Marnay (S et L): Soc Préhist Française Bull, v 71, no. 6, p 185-191.

Bonnet, A, du Cailer, J, and Royer, P, 1946, Ossements préhistoriques de La Sartanette à Remoulins, Gard: Soc Etudes Sci Nat Nîmes Bull, v 48, p 125-136.

Bonnet, A, Gutherz, X, and Pelenc, J N, 1973, Fosses néolithiques datées par le C 14 à la grotte de La Sartanette (Remoulins, Gard): Soc Préhist Française Bull, v 70, p $157-160$.

Castany, G, Marcé, A, Margat, J, Moussu, H, Vuillaume, Y, and Evin, J, 1974, Etude par les isotopes de milieu du régime des eaux souterraines dans les aquiféres de grandes dimensions: IAEA symposium on isotopes in hydrology, Vienna, SM $182 / 26$, p 243-258.

Chapotat, G, David, L, Evin, J, Guérin, C, and Walter, B, 1980, Chronologie des terrasses alluviales quaternaires de la moyenne vallée du Rhône. Datation par le radiocarbone: Acad Sci (Paris) Comptes rendus, ser D, in press.

Chapotat, G, Evin, J, Méry, A, and Samuel, E, 1978, Archéologie, datation radiocarbone, anthropologie et paléobotanique dans la vallée moyenne du Rhône en amont de Vienne: Soc Linnéenne Lyon Bull, v 47 no. 10, p 606-629.

Cheikh Anta Diop, 1977, Institut Fondamental d'Afrique noire radiocarbon dates II: Radiocarbon, v 19, p 161-164.

Clot, A and Cantet, M, 1974, La grotte ornće du Bois du Cantet, à Espèche (Hautes Pyrénées): Gallia Préhist, v 17, no. 1, p 69-100.

Clot, A and Omnès, J, 1979, Premiers datages radiocarbone du Magdalénien des Hautes Pyrénées: Soc Préhist Française Bull, in press.

Clottes, J, 1976, La grotte de Foissac: Cong UISPP 9th, Nice, 1976: Livret-guide de l'excursion A 5: Les Pyrénées, p 147-161.

Cogoluènhes, A, 1979, La grotte sépulchrale du Fournet: Thesis, Univ Lyon, in press.

Combier, J and Vuillemey, M, 1976, La grotte d'Arlay: Cong UISPP 9th, Nice, 1976: Livret-Guide de l'excursion A 8: Le Bassin du Rhône, p 74-81.

Coulonges, L, 1963, Magdalénien et Périgordien post-glaciaire. La grotte de la Borie del Rey (Lot et Garonne): Gallia Préhist, v 6, p 1-29.

Crémillicux, A, 1974, Stratigraphie, typologie et palethnologie de quelques remplissages d'abris sous-basaltiques en Haute vallée de la Loire (Velay): Documents Lab Géol Faculté Sci Lyon, v 62, 127 p.

Daugas, J, Evin, J, Paquereau, M M, Raynal, J P, and Tixier, L, 1978, Eléments de datation pour la basse terrasse de l'Allier à Joze (Puy de Dôme): Nouv Achives Mus Lyon, v 16, p 59-62.

David, L, Evin, J, Guérin, C, Mongereau, N, and Walter, B, 1972, Datation par le radiocarbone de la terrasse quaternaire de Saint-Rambert d'Albon (Drôme). Würm de la moyenne vallée du Rhône: Acad Sci (Paris) Comptes rendus, ser D, v 274, p 2007-2008.

Delibrias, G, Guillier, M T, Ervin J, Thommeret Y; 1976, Les datation ${ }^{14} \mathrm{C}$ Paléolithique supérieur en France: La Préhistoire Française, v 1, p 1509-1512.

Delibrias, G, Guillier, M T, Labeyrie, J, 1966, Gif natural radiocarbon measurements I: Radiocarbon, v 8, p 128-141. $280-320$ 
Desbrosse, R, 1976, Les civilisations du paléolithique supérieur dans le Jura méridional et dans les Alpes du Nord: La Préhistoire Française, Paris CNRS Press, $\mathrm{v} 1, \mathrm{p} 1196-1213$.

De Vries, H L and Waterbolk, H T, 1958, Groningen radiocarbon dates III: Science, v 128, p 1550-1556.

Elouard, P, 1968, Le Nouakchottien, étage du Quaternaire de Mauritanie: Annales Fac Sci Dakar, v 22, p 121-137.

Elouard, P and Faure, H, 1967, Quaternaire de l'Inchiri, du Taffoli et de la région de Nouakchott: Cong Panafricain de Préhist 6th, Comptes rendus, p 466-492.

Elouard, P, Philibert, P, Debard, E, Mçon-Vilain, H, and Crémillieux, A, 1974, Coupe géologique et interprétation climatique du gisement préhistorique post-würmien de Longetraye: Soc Languedocienne Géogr Bull, v 8, no. 3-4, p 275-284.

Evin, J, Chauviré-Mourer, C, and Philippe, M, 1980, Les gisements de vertébrés pléistocènes des Causses de Martel et de Gramat: Chronologie relative et datations ${ }^{14} \mathrm{C}$ : Nouvelles arch Mus Lyon, in press.

Evin, J, Longin, R, Marien, G, and Pachiaudi, C, 1971, Lyon natural radiocarbon measurements II: Radiocarbon, v 13, p 52-73.

Evin, J, Longin, R, and Pachiaudi, C, 1969, Lyon natural radiocarbon measurements I: Radiocarbon, v 11, p 112-117.

Evin, J and Maréchal, J, 1979, Conditions involved for getting reliable dates from gasteropoda shells: $\mathrm{ms}$ in preparation.

Evin, J, Marien, G, and Pachiaudi C, 1973, Lyon natural radiocarbon measurements III; Radiocarbon, v 15, p 134-155. 514-533. 1973, Lyon natural radiocarbon measurements IV: Radiocarbon, v 15, p 4-34.

1975, Lyon natural radiocarbon measurements V: Radiocarbon, v 17, p 60-88. $19-57$.

Evin, J, Mongereau, N, and Rousselot, D, 1979, Utilisation du radiocarbone pour une meilleure connaissance de l'alimentation des nappes aquifères. Origine des eaux souterraines du couloir fluvio-glaciaire de Meyzieux (69): Réunion annuclle Sci de la Terre 7th, Comptes rendus, Lyon, April 1979, p 182.

Guillaume, C, 1974, A Saint-Mihiel: extraction et taille de silex il y a 4000 ans: Archéologia, v 67, p 40-49.

1978, La grotte sépulcrale néolithique des "Roches de la Frasse" à Novéantsur-Moselle (Moselle): Rev archéol de l'Est et du Centre-Est, v 29, no. 3-4, p 265.

Hannss, C, 1977, Spätpleistozäne bis postglaziale Talverschüttungsund Vergletcherungsphasen im Bareich des Sillon Alpin der französischen Nord-alpen: Thesis, Univ Tübingen, $2 \mathrm{v}$, in press.

Haricot, M, 1978, Eperon barré de Montgasteau, Cne de St-Denis-les-Ponts: Comptes rendus Colloque interrégional sur le Néolithique, Saint-Amand-Montrond, April 1978 , in press.

Hassko, B, Guillet, B, Jaegy, R, and Coppens R, 1974, Nancy natural radiocarbon measurements III: Radiocarbon, v 16, p 118-130.

Jarrige, J F and Enault, 1976, Les fouilles de Pirak: Arts asiatiques, v 32, p 29-70.

Lagier-Bruno, L, 1973, Les blocs à cupules et à bassins de la région de Yenne-Belley: Rev Le Bugev, v 60, p 5-31.

Lechevallier, M and Valla, F, 1974, Mallaha (Eynan): Paléorient, v 2, no. 1.

Lepape, A, 1970, Buderfeld: Etudes Mosellanes, v 3, p 179-191.

Leroi-Gourhan, Arl and Allain, J, 1979, Lascaux inconnu: 12th supp Gallia Préhist, in press.

Leroi-Gourhan, Arl and Evin J, 1979, Les datations de Lascaux: ibid, p 81-86.

Libby, W F, 1955, Radiocarbon dating: Chicago, Univ Chicago Press, 175 p.

Mazière, G, 1978, Le Paléolithique en Corrèze: Thesis, Univ Paris, 526 p.

Mazière, G and Raynal, J P, 1977, La fin des temps glaciaires en Limousin: Colloquium internatl CNRS Comptes rendus "La fin des temps glaciaires en Europe, Bordeaux, May 1977, Preprint, v 2, p 267-285.

1978, Le gisement de Chez-Jugie près de Cosnac; Campagne de fouilles 1977: Soc Lettres Sci Arts de Corrèze, Bull, v 18, p 31-35. 
Mohen, J P, 1973, Les Tumulus de Bougon, nécropole néolithique: Soc Hist et Sci Deux-Sèvres, Bull, v 1973, no. 2-3, 54 p.

1977, Les Tumulus de Bougon: cinq années de recherches (1972-1977): Soc Hist et Sci Deux-Sèvres, Bull, v 1977, no. 2-3, 48 p.

Monteillet, J, 1974, Etude quantitative d'un échantillonage de faune Quaternaire récent de la région de Saint-Louis, Sénégal: Inst Fondamental Afrique noire Bull, ser A, v 36, p 257-290.

Omnès, J, 1977, La préhistoire au Calvaire de Lourdes: découvertes anciennes et nouvelles: Recherches sur Lourdes, v 60, p 229-232.

Piningre, J F and Vuillemey, M, 1976, Les civilisations du Paléolithique moyen en Franche-Comté: La Préhistoire Française, Paris, CNRS press, v 1, p 1120-1130.

Pradel, L and Chollet, A, 1950, L'abri périgordien de Laraux, commune de Lussac-les Châteaux, Vienne: L'Anthropologie, v 54, no. 3-4, p 214-227.

Reille, M, 1976, Analyses polliniques de sédiments post-glaciaires dans le Haut Atlas marocain: premiers résultats: Ecol Mediterranea, v 2, p 153-170.

1977. Contribution pollenanalytique à l'histoire holocène de la végétation des montagnes du Rif: Assoc française Etudes Quaternary Bull, v 50, p 53-76.

Robert, D and Robert, S, 1979, Recherches archéologiques à Tegdaoust et KoumbiSaleh: Annales Inst Mauritanien Recherches Sci, in press.

Taborin, Y, 1977, Les habitats palèolithiques des bords de la Seine: Etioles: Colloquium internatl CNRS Comptes rendus "La fin des temps glaciaires en Europe, Bordeaux, May 1977, preprint v 2, p 116-132.

Le Tensorer, J M 1979, Recherches sur le Ouaternaire du Lot et Garonne: stratigraphie, paléoclimatologie et préhistoire paléolithique, Thesis, Univ Bordeaux III, 812 p.

Thévenin, A, 1976, Informations archéologiques: Gallia Préhist, v 19, p 490.

Thévenin, A, Gies, C, Sainty, J, Scheider, M L, Jeunesse, C, and Rapp, J P, 1977, Le site néolithique de Reichstett, fouilles de 1976: Revue Archéol de l'Est et du Centre-Est, v 28, no. 3-4, p 175-228.

Thilmans, G and Descamps, C, 1974, Le site mégalithique de Tiékène-Boussoura (Sénégal). Fouilles de 1974-1975: Inst Fondamental Afrique noire Bull, v 37, ser B, no. 3 , p 447-496. 1975, Le site mégalithique de Tiékène-Boussoura (Sénégal). Fouilles d
1974-1975: Inst Fondamental Afrique noire Bull, v 37, ser B, no. 2, p 261-306.

Triat-Laval, H, 1978, Contribution pollenanalytique à l'histoire tardi et post-glaciaire de la végétation de la Basse Vallée du Rhône: Thesis, Univ Marseille, 308 p.

Vivian, R, 1975, Les glaciers des Alpes occidentales, études géographique: Allier press, Grenoble, $513 \mathrm{p}$.

Vogel, J C and Waterbolk, H T, 1963, Groningen radiocarbon dates IV: Radiocarbon, v 5, p 163-202.

1964, Groningen radiocarbon dates V: Radiocarbon, v 6, p 349-369.

1969, Groningen radiocarbon dates VII: Radiocarbon, v 9, p 107-155.

1972, Groningen radiocarbon dates X: Radiocarbon, v 14, p 6-110. 